School of Finance

University of St.Gallen

MANAGEMENT INFLUENCE ON INVESTORS: EVIDENCE FROM SHAREHOLDER VOTES ON THE FREQUENCY OF SAY ON PAY

FABRIZIO FERRI

DAVID OESCH

WORKING PAPERS ON FinANCE No. 2013/29

SWISS INSTITUTE OF BANKING AND FINANCE (S/BF - HSG)

OCTOBER 2013 


\title{
Management influence on investors: evidence from shareholder votes on the frequency of say on pay
}

\author{
Fabrizio Ferri* \\ Columbia University \\ ff2270@columbia.edu \\ David Oesch \\ University of St. Gallen \\ david.oesch@unisg.ch
}

\begin{abstract}
:
The literature on shareholder voting has mostly focused on the influence of proxy advisors on shareholder votes. We exploit a unique empirical setting enabling us to provide a direct estimate of management's influence. Analyzing shareholder votes on the frequency of future say on pay votes, we find that a management recommendation for a particular frequency is associated with a $26 \%$ increase in voting support for that frequency. Additional tests suggest that the documented association is likely to capture a causal effect. Management influence varies across firms and is smaller at firms where perceived management credibility is lower. Compared to firms adopting an annual frequency, firms following management's recommendation to adopt a triennial frequency are significantly less likely to change their compensation practices in response to an adverse say on pay vote, consistent with the notion that a less frequent vote results in lower management accountability.
\end{abstract}

JEL Classification: G34, G38, J33, M12

Keywords: Say on pay, say when on pay, shareholder votes, management influence, CEO compensation, shareholder activism

\footnotetext{
* Corresponding Author: Columbia Business School, Columbia University, Uris Hall 618, 3022 Broadway, New York, NY 10027, phone: (212) 854-0425.

We thank Carol Bowie (at Institutional Shareholder Services) and Robert McCormick (at Glass Lewis \& Co.) for insightful conversations, Edward A. Hauder at Exequity LLP for providing data on the adoption of frequency of say of pay, Dirk Black (discussant), Martijn Cremers (discussant), Eitan Goldman (discussant), Yaniv Grinstein, Wayne Guay, Peter Iliev and seminar/conference participants at Boston University, Catholic University of Milan, Columbia University, the University of Michigan, the University of Washington, the University of Colorado at Boulder, Northwestern University, London Business School, London School of Economics, the 2013 Financial Economics and Accounting Conference, the 2014 American Finance Association annual meeting and the 2014 Corporate Governance Symposium at the University of Delaware. The paper has been accepted for presentation at the 2014 American Law \& Economics Association (ALEA) annual meeting. Fabrizio Ferri acknowledges a grant from the Eugene M. Lang Support Fund of Columbia Business Schools. All errors remain our own.
} 


\section{Introduction}

We provide an estimate of the influence of management recommendations on shareholder votes and examine its determinants and consequences. The increasing influence of non-binding shareholder votes on firms' governance and compensation practices over the last decade calls for a better understanding of their determinants. ${ }^{1}$ While a number of studies document the considerable influence of proxy advisors' recommendations, ${ }^{2}$ we know very little about the influence of management recommendations on shareholder votes. The challenge in empirically evaluating this influence is that management recommendations are typically the same across firms (e.g. in favor of (against) management (shareholder) proposals), making it impossible to estimate their impact. ${ }^{3}$

We exploit a unique empirical setting that allows us to quantify management influence on shareholder votes. Section 951 of the Dodd-Frank Act mandated a non-binding shareholder vote in 2011 on executive pay, known as "say on pay" vote (SOP). More importantly for our purpose, it also mandated a non-binding vote on the frequency of future SOP votes (known as "say when on pay" vote, or SWOP), with a choice between an annual, a biennial or a triennial frequency. Supporters of annual SOP votes argued that it would promote greater accountability, while proponents of a triennial frequency argued that it would better align the vote with the long-term

\footnotetext{
${ }^{1}$ For a recent review of the empirical literature on shareholder voting, see Ferri (2012). The costs and benefits of greater shareholder involvement in corporate governance remain the subject of ongoing debate (e.g. Bebchuk 2005; Bainbridge 2006; Kahan and Rock 2011), with empirical studies yielding mixed findings (Listokin 2009; Becker, Bergstresser and Subramaniam 2013; Cai and Walkling 2011; Cohn, Gillan and Hartzell 2013; Larcker, Ormazabal and Taylor 2011; Cuñat, Gine and Guadalupe 2012; Ferri and Maber 2013). Other studies have raised concerns with various aspects of the proxy voting process such as strategic vote trading or empty voting (Christoffersen, Geczy, Musto and Reed 2007; Hu and Black 2007; Bethel, Hu and Wang 2009; SEC 2010; Aggarwal, Saffi and Sturgess 2012).

${ }^{2}$ Proxy advisory firms provide proxy-voting services to institutional investors on a subscription basis, including voting recommendations and reports detailing the analysis underlying these recommendations. See, among others, Cai, Garner and Walkling (2009), Fischer, Gramlich, Miller and White (2009), Alexander, Chen, Seppi and Spatt (2010), Ertimur, Ferri and Muslu (2011), Larcker, McCall and Ormazabal (2012) and Ertimur, Ferri and Oesch (2013).

${ }^{3}$ Throughout the paper we use the term "management" recommendations to refer to voting recommendations made by the board of directors.
} 
nature of the compensation plan and the firm's strategy. The distinguishing feature of our setting is that, in contrast to other shareholder voting settings, proxy advisor recommendations are the same across all firms (in favor of an annual frequency) but management recommendations vary across firms, allowing us to estimate and examine their association with shareholder votes. ${ }^{4}$

We begin by examining the determinants of the voting outcome in a sample of S\&P 1500 firms with annual meetings in 2011. At 61.6\% (35.4\%) of the sample firms management recommends an annual (biennial/triennial) SOP vote. ${ }^{5}$ Consistent with the preference voiced by many institutional investors, the annual frequency option is supported by $75.5 \%$ of the votes cast on average and obtains the highest number of votes in more than $90 \%$ of the firms. Similar to other studies, we find that size, performance and ownership structure are important determinants of shareholder votes (Ertimur, Ferri and Stubben 2010). More importantly for our research question, management recommendations are a key driver of the variation in voting outcomes. In multivariate tests, we estimate that management's support for a triennial frequency is associated with $25.9 \%$ more voting support for a triennial frequency (relative to the case where management recommends annual), a figure close to estimates of the influence of the most prominent proxy advisor, Institutional Shareholder Services, on voting outcomes (e.g. Ertimur et al. 2013).

A number of additional tests suggest that the association does not merely reflect a coincidence of preferences between management and shareholders (i.e. management and shareholders independently favor the same frequency) or reverse causality (i.e. the expected voting outcome drives management recommendations), but mostly captures a causal influence of management

\footnotetext{
${ }^{4}$ To our knowledge, the only other empirical setting that can be used to estimate the influence of management recommendations on shareholder votes is when from one year to another management changes its recommendation for a shareholder proposal to declassify the board. We will use this setting later in the paper to validate our findings, but it should be noted that, unlike the frequency vote we focus on, it only involves a small and potentially biased sample.

${ }^{5}$ Throughout the paper, we group together the cases of biennial and triennial recommendations, since they are based on similar arguments and the number of biennial recommendations is very small (see Table 1). All the results presented are robust to excluding the cases of biennial recommendations.
} 
recommendations on shareholder votes. Notably, we also obtain a similar estimate of management influence $(24.4 \%)$ in a setting potentially less affected by reverse causality concerns, that is, a sample where a shareholder proposal to declassify the board opposed by management wins a majority vote and is then followed the subsequent year by a management proposal to amend the certificate of incorporation and declassify the board. ${ }^{6}$

Next, we analyze the determinants of management influence on shareholder votes and find that management attracts significantly less support for a triennial recommendation when shareholders have expressed concerns with the firm's pay practices (as reflected in the contemporaneous shareholder vote on SOP), and with management performance and initiatives (as reflected in shareholder votes on director elections and management proposals). Voting support for triennial is also lower in firms with low management forecast accuracy. Instead, we find no association between proxies for the duration of the compensation plan (in the spirit of Gopalan, Milbourn, Song and Thakor 2012) and shareholder votes. Collectively, these results suggest that management credibility with shareholders is a key determinant of its influence on voting outcomes.

We then track the SOP frequencies adopted by firms in the aftermath of the SWOP votes. Interestingly, despite the votes being non-binding, virtually all companies decided to adopt the SOP frequency that garnered most votes-another example of the growing influence of nonbinding shareholder votes on boards' choices (e.g. Ertimur et al. 2013).

Next, we turn our attention to the consequences of the documented management influence. In particular, we examine whether firms that adopted a triennial frequency (because shareholders trusted management recommendations and voted for triennial, essentially giving up some

\footnotetext{
${ }^{6}$ Our estimates are likely to be a lower bound estimate of management influence, since they are based on settings (frequency of SOP, board declassification) where many institutional investors' preferences are predetermined (in favor of annual SOP votes, in favor of declassifying the board). On other matters on the ballot where more votes are "in play", management's opportunity to influence shareholder votes is likely to be bigger.
} 
monitoring power)—and, thus, facing the next SOP vote in 2014-were less likely to make changes to their pay practices in response to adverse SOP votes compared to firms adopting an annual frequency and, thus, facing the next SOP vote in 2012 already. To perform this test, we expand our sample to the Russell 3000 index and identify 273 firms (203 annual adopters, 70 triennial adopters) likely to be under pressure to respond to the SOP vote (i.e. firms that received a negative ISS recommendation on the SOP proposal, averaging $29.8 \%$ votes against SOP in 2011).

We find that $67.5 \%$ of the annual adopters made changes to their compensation plan directly in response to the 2011 vote. In stark contrast, only $14.3 \%$ of the triennial adopters made similar changes (difference statistically significant at the $1 \%$ level). A potential explanation is that compensation changes made by annual adopters are immaterial and artificially inflate the rate of responsiveness relative to the triennial firms. However, annual adopters reporting changes to their compensation plan experience a large decrease in votes against SOP (from 39.6\% in 2011 to $19.6 \%$ in 2012 , on average) suggesting that these changes are perceived by voting shareholders as an adequate and material response to the 2011 vote.

Another explanation is that triennial adopters are less responsive because they experience lower SOP voting dissent relative to annual adopters (16.0\% versus $34.5 \%$ ) or because of other firms' characteristics found to be associated with firms' responsiveness to shareholder pressure (e.g. institutional ownership, size, performance). Our multivariate tests indicate indeed that firms experiencing greater voting dissent, firms with higher institutional ownership and firms with lower performance are more likely to change compensation practices in response to SOP votes. However, the adoption of a triennial frequency continues to be a statistically and economically significant factor: holding all other variables at the median, the likelihood of compensation changes is $39 \%$ for triennial adopters versus $62 \%$ for annual adopters. Overall, our evidence of 
lower responsiveness by triennial adopters is consistent with the view (expressed by supporters of annual SOP votes) that a less frequent vote would reduce management accountability. It also suggests that management may have used its significant influence over shareholder votes to reduce scrutiny over its compensation via a less frequent SOP vote.

Finally, we complete our analysis by examining the determinants of management recommendations. We find that management is more likely to recommend triennial SOP votes when the percentage of votes controlled by insiders is higher and the percentage of votes controlled by institutional investors (particularly those who publicly expressed support for annual SOP votes) is lower, consistent with the idea that management's recommendation decision takes into account the expected voting outcome because ignoring an adverse vote is costly. Indeed, the frequency of management recommendations drops dramatically, from around $60 \%$ to $30 \%$, after the first part of the proxy season, as widespread shareholder support for annual SOP votes became apparent. Management's perception of the chance of winning the vote matters, too, with overconfident CEOs more likely to recommend triennial SOP votes. Interestingly, we do not find a significant relation between proxies for the duration of the compensation plan and the likelihood of a triennial recommendation, contrary to the arguments put forth by management when motivating their recommendation. In contrast, we find that firms with higher abnormal CEO pay are more likely to recommend triennial SOP votes. Combined with the evidence of lower responsiveness to SOP votes, this result is consistent with firms recommending triennial SOP votes to avoid the more frequent scrutiny of CEO pay associated with annual votes.

Shareholder votes have emerged as an important performance metric and control system (Fischer et al. 2009). Our study contributes to the literature on shareholder voting by providing the first estimate of the influence of management recommendations. In doing so, it adds to a limited 
body of research on indirect ways through which management may try to influence the voting outcome (e.g. bundling, classifying and timing proposals up for a vote, increasing voting turnout). ${ }^{7}$ Combined with the evidence from studies on proxy advisors, our estimate suggests that, on average, proxy advisors and management influence about one fourth of the total votes each, with the remaining votes (about half of the total votes) essentially representing "votes in play". Hence, while growing attention is devoted to the influence of proxy advisors on shareholder votes and its dangers (e.g. Choi et al. 2010; Larcker et al. 2012; Larcker, McCall and Ormazabal 2013; Ertimur et al. 2013), our evidence calls for more research on the pros and cons of management influence, at a time where firms are trying to expand such influence (WSJ 2013). ${ }^{8}$

Our study also contributes to the literature on executive pay and, in particular, on say on pay and compensation-related activism (Cai and Walkling 2011; Ertimur et al. 2011, 2013; Armstrong, Gow and Larcker 2013; Ferri and Maber 2013). Our evidence that firms under a triennial regime are less likely to respond to shareholder pressure and implement changes to their compensation plans implies that the threat of other (potentially substitute) monitoring tools (e.g. withholding votes from compensation committee members, filing shareholder proposals, informal engagement

\footnotetext{
${ }^{7}$ Bebchuk and Kamar (2010) find that management is able to use "bundling" to obtain shareholder approval for promanagement arrangements (e.g. staggered boards) which shareholders would not support on a stand-alone basis. Bethel and Gillan (2002) document that management opportunistically used discretion in the classification of management proposals as "routine" proposals at a time when (for routine proposals) brokers were allowed to vote uninstructed shares held in street name (with these shares typically voted in favor of management). Studying a sample of mergers, Listokin (2010) documents that close-call management proposals are more likely to pass by a small margin than to fail by a small margin, consistent with management timing the submission of proposals when they are more likely to be approved or successfully soliciting votes when the outcome is uncertain. Dimitrov and Jain (2011) and Baginski, Clinton and McGuire (2013) find that management discloses positive news ahead of contentious annual meetings, while DeAngelo (1988) finds evidence of income-increasing earnings management before shareholder votes on proxy contests. Young, Millar and Glezen (1993) find that management mails proxies in advance to obtain a higher voting turnout when its proposals require a majority of shares outstanding, as opposed to votes cast, for approval. Ferri and Sandino (2009) provide anecdotal evidence of firms' efforts to win the shareholder vote (e.g. the case of Intel on a shareholder proposal to expense stock options). Another line of research examines the extent to which actual or potential business opportunities (another form of indirect management influence) affect the votes of mutual funds (e.g. Davis and Kim 2007).

${ }^{8}$ Recent reports suggest that firms are investing more resources in soliciting votes from retail investors and are lobbying regulators to be able to obtain the names of large retail shareholders from brokers (WSJ 2013).
} 
with the board) is less effective than the threat of an imminent SOP vote. Also, while a large body of research has focused on management influence on boards as a way to extract compensation rents (e.g. Bebchuk and Fried 2004), we examine the use of management influence on shareholders as a way to reduce scrutiny over executive pay.

Relatedly, we contribute to the research on boards' responsiveness to shareholder pressure (e.g. Del Guercio, Seery and Woidtke 2008; Ertimur et al. 2013; Ferri and Maber 2013). Our evidence of lower responsiveness to shareholder votes in firms with lower frequency of scrutiny (triennial SOP vote) echoes the result that firms with classified boards (another form of less frequent scrutiny) are less likely to implement majority-approved shareholder proposals (Faleye 2007).

Finally, the study speaks to the accounting literature on management influence on investors. While this literature has focused on the credibility of management forecasts for the marginal investor (e.g. Rogers and Stocken 2005; Ng, Tuna and Verdi 2013), we examine the credibility of management recommendations for voting shareholders.

\section{Sample description, frequency of recommendations and voting outcome}

Our sample includes S\&P 1500 firms with annual meetings in 2011 for which we are able to obtain voting data and management recommendations from Institutional Shareholder Services (ISS), as well as the relevant financial, compensation and governance data from CRSP, Compustat, Execucomp and RiskMetrics, resulting in 1,365 firms. Table 1 indicates that in $61.6 \%$ of the cases (841 firms) management recommended annual SOP votes, in $35.4 \%$ of the cases it recommended either a biennial (32 firms) or a triennial (452 firms) frequency, whereas in $2.9 \%$ of the cases (40 firms) it made no recommendation. Notably, as shown in Figure 1, the frequency of multiyear (biennial or triennial) recommendations was considerably higher, around $60 \%$, in the early part of 
the proxy season (annual meetings between January and March 2011), and then dropped to around $30 \%$, likely in response to early evidence of shareholders' preference for annual SOP votes.

Appendix 1 presents examples of the arguments in support of the various recommendations. Firms favoring a triennial vote generally argue that it is more consistent with the long-term nature of their compensation plan and business strategy and allows more time for shareholders to evaluate the effectiveness of the compensation plan (as well as firms' responses to the vote) and for boards to obtain and implement shareholders' suggestions. They also contend that, even with triennial votes, shareholders will continue to have opportunities for more timely feedback through direct engagement with the board. Firms supporting the annual frequency state that it promotes greater accountability, more timely feedback on compensation decisions and is consistent with the annual evaluation performed by the compensation committee. Similar arguments are echoed by proxy advisors and institutional investors (see Appendix 2), who also note that an annual vote is easier to interpret, is the standard adopted by other countries with a SOP regime, is consistent with annual votes on auditor ratifications and the trend toward annual election of directors and may avoid more confrontational tactics (e.g. vote-no campaigns) in the "off" years.

Many institutional investors expressed their position on the SOP frequency choice ahead of the proxy season, in most cases expressing support for an annual frequency. ${ }^{9}$ In fact, Table 1 indicates that shareholders overwhelmingly favored an annual SOP vote $(75.5 \%$ of the votes, versus $21.3 \%$ in favor of triennial and only $1.7 \%$ in favor of biennial). Even more strikingly, in $90.8 \%$ of the cases $(1,239$ out of 1,365$)$ the annual option received the highest voting support (almost always also representing the majority of votes cast). Table 1 also provides a first glimpse of the influence

\footnotetext{
${ }^{9}$ The list of those favoring annual SOP votes includes (among others) Fidelity, Putnam, State Street, CalPERS, CalSTRS and TIAA-CREF, while Blackrock, Capital Research and Ontario Teachers' Pension Plan (OTTP) favored a triennial frequency. In some cases, the position was more nuanced. Vanguard, for example, generally favored an annual frequency but would consider supporting a triennial frequency if the compensation plan was multi-year in nature. For a (partial) list of institutional investors' policy on SWOP, see http://say-on-pay.com/shareholder-positions/.
} 
of management recommendations on voting outcomes. Voting support for any of the three options is about $30 \%$ higher when recommended by management. For example, mean voting support in favor of annual is $86.6 \%$ when management recommends annual and $56.5 \%$ when management recommends triennial. ${ }^{10}$ An interesting and unique feature of our setting is that we also observe how shareholders vote in a sample of 40 firms where management makes no recommendation: on average $71.5 \%$ of the votes were cast in favor of annual (Table 1, last column). One way to interpret this figure is that about half of the (approximately) $30 \%$ votes otherwise influenced by management were cast in favor of annual and the rest in favor of biennial and triennial.

\section{Determinants of shareholder votes on the frequency of SOP}

\subsection{Estimating management influence on shareholder votes}

To examine the determinants of the SWOP votes, we estimate an OLS regression where the dependent variable is SWOP Votes for Triennial (i.e. the percentage of votes cast in favor of holding a biennial or triennial SOP vote). ${ }^{11}$ Similar to other studies on the determinants of shareholder votes, we control for size ( $\ln (M V$ Equity)), performance (Return on Assets, Abnormal Returns) and ownership structure. ${ }^{12}$ With respect to the latter, we include three components: insider ownership, institutional ownership and ownership by non-institutional blockholders. For insider ownership, we hand-collect from proxy statements the percentage of shares owned by directors and executives and then adjust it to take into account actual voting rights arising from dual class structures or the existence of other securities (e.g. preferred stock) with voting rights.

\footnotetext{
${ }^{10}$ Another way to obtain the same estimate from Table 1 is the following: regardless of any recommendations, about $57 \%$ of the votes are cast in favor of annual and about $12-13 \%$ in favor of biennial/triennial, implying that the remaining (approximately) 30\% of the votes cast move with management recommendations.

${ }^{11}$ We obtain similar findings when we use the logit transformation of SWOP Votes for Triennial, log [(SWOP Votes for Triennial / (1 - SWOP Votes for Triennial)], as in Bethel and Gillan (2002). For ease of interpretation we present the results using SWOP Votes for Triennial as the dependent variable.

${ }^{12}$ Previous studies find that voting support for management is generally higher in larger firms possibly due to the higher cost of collective action in large firms and the greater resources they invest in campaigning, and in better performing firms (e.g. Ertimur et al. 2010; Gillan and Starks 2000).
} 
That is, unlike prior studies on shareholder voting, we effectively measure the percentage of votes controlled by directors and executives (rather than the percentage of common shares held), \% Votes Controlled by Insiders. ${ }^{13}$ The correction is important. For firms with triennial recommendations where the correction is necessary, the mean \% Votes Controlled by Insiders before (after) the adjustment is $22 \%(55 \%)$. As for institutional ownership, we first compute the percentage of shares held by institutional investors (rescaled to account for the adjustment of insider ownership described above), \% Institutional Ownership. Then, we exploit the fact that a number of institutional investors publicly declared their support for annual or triennial SOP votes before the beginning of the proxy season and split the \% Institutional Ownership variable into three variables: the percentage of equity held by institutional investors In Favor of Annual, In Favor of Triennial or With No Stated Preference. ${ }^{14}$

The third component of ownership structure we measure is the percentage of shares held by investors owning more than $5 \%$ of equity (and thus reported in the proxy statement) but not subject to the 13-F filing requirements (and thus not captured by standard measures of institutional ownership), denoted as \% Non-Inst. Block Ownership (rescaled to account for the adjustment of insider ownership described above). This category, neglected in prior studies on shareholder voting, includes a heterogeneous group of investors, such as corporate owners, private equity

\footnotetext{
${ }^{13}$ As an extreme example, consider a company with 100 Class A shares (with one vote per share) and 10 Class B shares (with ten votes per share), where executives and directors own 10 A shares (10\% of Class A) and 10 B shares (100\% of Class B). Available databases will report a 10\% ownership figure (based on Class A shares) or a $18.2 \%$ figure (based on Class A and B: $(10+10) / 100+10)$ ), while the percentage of votes controlled by executives and directors is $55 \%$, calculated as $(10+100) /(100+10 * 10)$.

${ }^{14}$ To classify institutional investors as In Favor of Annual or In Favor of Triennial we start with the list compiled by Edward A. Hauder at Exequity LLP (http://say-on-pay.com/shareholder-positions/) and complement it with other web sources. Every other institutional investor is classified as With No Stated Preference. The mean percentage ownership for three groups is $11.7 \%$ (In Favor of Annual), 8.7\% (In Favor of Triennial) and 58.3\% (With No Stated Preference). Of course, it is possible that we mistakenly include in the last group some investors who disclosed their preference for annual or triennial but were not detected by our search.
} 
firms, wealthy individual investors, foreign investment firms, former CEOs/founders (not classified as insiders), firms' ESOPs and trusts (data hand-collected from proxy statements).

The results for this baseline specification (presented in Table 2, Panel A, Model (1)), indicate a positive (negative) association between votes in favor of triennial and \% Institutional Ownership in Favor of Triennial (in Favor of Annual), consistent with the preferences voiced by these institutions. The association between \% Institutional Ownership With No Stated Preference and votes in favor of triennial is negative, indicating that most of these institutions decided to support an annual frequency. The association between votes in favor of triennial and \% Votes Controlled by Insiders and \% Non-Institutional Block Ownership is positive and significant, suggesting that insiders and non-institutional blockholders on average supported a triennial frequency. Support for triennial is higher in more profitable firms. The adjusted R-square is $35.2 \% .^{15}$

Turning to our research question, in Model (2) we include an indicator equal to one if management recommends triennial SOP votes (Mgmt SWOP Rec: Triennial), to obtain an estimate of the influence of management recommendations in a multivariate setting. Consistent with the evidence in Table 1 , the indicator is positive and significant at 0.259 , suggesting that management recommendations (in this setting) are associated with approximately $26 \%$ higher voting support. $^{16}$ Notably, the adjusted R-square increases from $35.2 \%$ to $74.4 \%$, reflecting the significant

\footnotetext{
${ }^{15}$ In untabulated tests we further split \% Institutional Ownership With No Stated Preference based on institutional investors' potential conflict of interests (the "gray" versus "independent" classification in Brickley, Lease and Smith 1988) and on their horizon and investment behavior (the "dedicated", "transient" and "quasi-indexer" classification in Bushee 1998), but do not find significant differences among these subgroups. Also, note that, in Model (1), \% Votes Controlled by Insiders measures the percentage of equity held by insiders taking into account actual voting rights arising from dual class structure or the existence of other securities (e.g. preferred stock) with voting rights. When we replace \% Votes Controlled by Insiders with \% Insider Ownership, a measure that is not adjusted for differences in voting rights, the (positive and significant) coefficient on this measure is substantially smaller and the adjusted Rsquare decreases to $25.3 \%$, highlighting the importance of the correction.

${ }^{16}$ The sample size in Model (2) is slightly smaller because we exclude the 40 cases of no management recommendations. We also run a specification including these cases, with an indicator for annual and one for triennial recommendations. The coefficients on the annual and triennial recommendation indicators are, respectively, -0.142 and 0.119 (both significant at the $1 \%$ level), adding up to a $26 \%$ vote difference between annual and triennial. We choose to present the specification in Model (2) to obtain a direct estimate of management influence on shareholder votes and to enhance comparability with estimates of the influence of proxy advisors.
} 
explanatory power of management recommendations. As a benchmark, estimates of ISS influence on shareholder votes range between $20 \%$ and $30 \%$ depending on the topic and time period, with a similar increase in the adjusted R-square. ${ }^{17}$ While most studies focus on the (pros and cons of the) influence of proxy advisors (e.g. Alexander et al. 2010; Larcker et al. 2012), our estimate suggests that similar attention should be paid to the (the pros and cons of) management influence.

\subsection{Endogeneity concerns}

As with research on proxy advisors' influence on voting outcomes (see the discussion in Choi et al. 2010; Ertimur et al. 2013), endogeneity concerns suggest caution in inferring causality.

A first type of endogeneity concern arises due to reverse causality, that is, the possibility that the association documented in Model (2) of Table 2 reflects the effect of the expected voting outcome on management recommendations rather than the influence of management recommendations on shareholder votes. To examine this possibility, we perform three tests. First, in Model (3), we re-run Model (2) but split Mgmt SWOP Rec: Triennial into two indicators, depending on whether or not the vote takes place early in the proxy season (January-March 2011). As discussed earlier, there was a significant drop in the frequency of triennial recommendations after the realization that most shareholders supported annual SOP votes (see Figure 1). If the association documented in Model (2) only captures the expected voting outcome, we would expect the coefficient on Mgmt SWOP Rec: Triennial to be significantly lower in the first three months, when management at many firms apparently overestimated shareholder support for triennial SOP

\footnotetext{
17 The effect of ISS's recommendations on the percentage of shareholder votes has been estimated at $25 \%$ in the context of SOP votes (Larcker et al. 2012; Ertimur et al. 2013) and compensation-related shareholder proposals (Ertimur et al. 2011), 14-21\% for management proposals (Bethel and Gillan 2002) and between 13\% and 30\% for director elections, depending on the context and time period (Cai et al. 2009; Choi, Fisch and Kahan 2010; Ertimur, Ferri and Maber 2012). Also, Alexander et al. (2010) find that an ISS recommendation in favor of the dissident in proxy contexts increases the likelihood of the dissident's victory by $14 \%$ (from $41 \%$ to $55 \%$ ).
} 
votes (and optimistically recommended triennial). On the contrary, however, the results of Model (3) show that the coefficient is slightly higher in the first three months. ${ }^{18}$

Second, in Model (4) we replace Mgmt SWOP Rec: Triennial with its residual from a logistic regression of the likelihood of a triennial recommendation on its hypothesized determinants (see Section 5 for details). The residual aims to capture the effect of the management recommendation above and beyond the effect of other observable factors affecting the recommendation (including proxies for the expected voting outcome). The coefficient on Residual Mgmt SWOP Rec: Triennial is virtually identical at 0.254 and the adjusted R-square remains high at 0.716 .

Finally, we exploit an altogether different setting to obtain an estimate of the influence of management recommendations less likely to be attributable to the expected voting outcome. A number of studies find that the presence of a staggered board is associated with lower firm valuation (e.g. Bebchuk and Cohen 2005; Bebchuk, Cohen and Yang 2011; Cuñat et al. 2012). Not surprisingly then, shareholder proposals to declassify the board have been among the most frequent and successful, in terms of voting outcome and firms' subsequent adoption (Ertimur et al. 2010; Cuñat et al. 2012). Declassifying the board requires an amendment to the certificate of incorporation which, in turn, requires a shareholder vote. Hence, when the board decides to declassify the board in response to a shareholder proposal winning a majority vote, the subsequent year it must submit a management proposal to amend the certificate of incorporation to a shareholder vote. Over the period from 2001 until 2012, we identify 129 firms where a shareholder proposal to declassify the board was followed by an analogous management proposal the subsequent year. In all these cases, management had recommended to vote "against" the shareholder proposal, the shareholder proposal won the majority of the votes (averaging about

\footnotetext{
${ }^{18}$ In untabulated tests, we also interact the Post March 31 indicator with all variables and find that that the relation between voting outcome and the other economic determinants is similar before and after March $31^{\text {st }}$.
} 
$70 \%$ of votes in favor) and then management recommended to vote "for" its own declassification proposal, noting that it changed its recommendation from the prior year in view of broad shareholder support for the proposal. ${ }^{19}$

Using this sample of 129 firms (258 proposals), in Panel B, Model (1), we regress the percentage of votes in favor of declassifying the board on a set of firm-level determinants of voting outcomes such as size, ownership structure and performance. Then, in Model (2), we add Mgmt Recommends For, an indicator equal to one if management recommends in favor of declassifying the board (that is, equal to one in the case of management proposals). If the association between management recommendation and voting outcome documented in Table 2, Panel A, is merely reflecting reverse causality (management recommending triennial when expecting a favorable voting outcome), then the coefficient on Mgmt Recommends For in Panel B, Model (2) should not be different from zero. The reason is that if management changes its recommendation to align it with shareholders' preferences after observing the voting outcome in favor of the previous year's shareholder proposal, there should be no association between the new, favorable management recommendation and shareholder votes the subsequent year. That is, all else being equal, the voting outcome in the subsequent year should be similar to the previous year's voting outcome, with no incremental effect due to the revised management recommendation. Instead, as shown in Model (2), the coefficient is positive and significant at 0.244 , suggesting that $24.4 \%$ more votes are cast in favor of the proposal after the change in management recommendation, consistent with a causal effect of management recommendations on shareholder votes. ${ }^{20}$ Put differently, while the

\footnotetext{
${ }^{19}$ Because we want to capture the effect of a change in management recommendation from "against" to "for", we exclude (the few) cases where (i) management had made no recommendation on the shareholder proposal or (ii) management recommended against its own proposal the subsequent year (that is, it submitted the proposal because of the past year's majority support for it, but continued to recommend against it).

${ }^{20}$ Note that insider ownership in our sample is about $2 \%$, and thus, the $24.4 \%$ estimate cannot capture simply the effect of insider votes moving in favor of the proposal. Indeed, when we modify Model (2) to add an interaction term
} 
change in management recommendation is certainly driven by the expected voting outcome (based on the past year's vote on the shareholder proposal), its incremental association with shareholder votes is consistent with a causal influence. ${ }^{21}$

In addition to alleviating potential reverse causality concerns, this test also provides us with an alternative, "time-series" estimate of management influence on shareholder votes, which turns out to be close to the estimate obtained in the "cross-sectional" test of SOP frequency votes.

A second type of endogeneity concern arises due to omitted variables. In particular, it is possible that management recommendations simply coincide with shareholder preferences (that is, management and shareholders happen to agree on what firms benefit most from a triennial frequency) and the coefficient on the triennial recommendation captures unobservable factors (or observable factors that we cannot measure with precision) that affect both management recommendations and shareholder votes, hence overstating the extent of management influence. We believe the following piece of evidence alleviates this concern. As noted previously and as indicated in Figure 1, the frequency of triennial recommendations dropped from $60 \%$ to $30 \%$ after the first three months of the proxy season (January $1^{\text {st }}-$ March $31^{\text {st }}$ ), as it became clear that the majority of voting shareholders preferred annual SOP votes. Hence, it is likely that in the second part of the proxy season (from April $1^{\text {st }}$ on) many firms that would have recommended triennial (had they not been influenced by the voting results of the first part of the proxy season) chose to recommend an annual SOP vote. If the coefficient on triennial recommendations in Table 2 simply

\footnotetext{
between the favorable management recommendation and insider ownership, the coefficient on the indicator for the favorable management recommendation only drops to 0.228 , with the interaction term being significantly positive.

${ }^{21}$ An alternative explanation is that $24.4 \%$ more votes are cast in favor of declassifying the board because some shareholders decide to vote in favor after seeing the voting outcome in the previous year. However, many of the shareholder proposals in our sample were submitted and won a majority vote for two or more years before management decided to submit a management proposal, and the percentage of votes cast in favor of those proposals was similar over time. In other words, it does not appear that shareholder proposals winning a majority vote with, say, $60 \%$ of the votes in favor, obtain more votes the following year when submitted again. The "bump" only occurs when management submits a proposal and changes its recommendation.
} 
captures cases where management and some shareholders independently happen to favor triennial SOP votes, then among firms recommending annual SOP votes in the second part of the proxy season there should be a significant number of cases with high shareholder support for triennial (i.e. firms that would have recommended triennial had they not been influenced by the voting results of the first part of the proxy season).

To examine this conjecture, we proceed as follows. If the frequency of triennial recommendations after March $31^{\text {st }}$ had remained the same as in the first three months, there should have been about 250 more cases of triennial recommendations. If shareholders at these firms voted independently from management recommendations, we should see an average voting support for triennial SOP votes of about $40 \%$ (that is, similar to the voting support when management recommends triennial; see Table 1). While we cannot identify these firms (i.e. firms that recommended annual but would have preferred to recommend triennial), we take a conservative approach and look at the 250 firms with the highest support for triennial among the 802 firms with annual recommendations after March $31^{\text {st }} \cdot{ }^{22}$ We find that the average voting support for triennial at these firms is $17.1 \%$, thus well below the $40 \%$ reported for the actual cases of triennial recommendations. Even when we look at the 100 firms with the highest support for triennial among firms with annual recommendations after March $31^{\text {st }}$, the average support for triennial, at $22.0 \%$, is still considerably below $40 \%$. Based on these figures, it appears that the association between shareholder voted and management recommendations is likely (and mostly) the result of management influence on shareholder votes rather than the manifestation of a coincidence in preferences between management and shareholders.

\footnotetext{
${ }^{22}$ In doing so, we essentially use shareholder voting support for triennial as a proxy for predicted management preference for triennial recommendations. Alternatively, we could identify firms with the highest predicted probability of recommending triennial (among firms recommending annual) based on some variation of the model in Table 7 . But voting support for triennial would be even lower, since our sample of predicted triennial recommendations by definition has the highest voting support for triennial SOP votes.
} 
Overall, our evidence suggests that our estimate of the association between management recommendations and shareholder votes mostly captures an incremental and causal effect of management recommendations on shareholder votes.

\subsection{What determines the extent of management influence?}

Is the estimate of management influence obtained in Table 2 similar across firms, reflecting certain shareholders' policy to "blindly" follow management recommendations, or does it vary cross-sectionally? If so, what factors determine the extent of management influence?

We start from the premise that by voting in favor of a triennial frequency shareholders essentially renounce some monitoring power and, thus, "trust" management with more discretion over compensation choices. Hence, we expect shareholders to be less likely to follow managements' triennial recommendations when management credibility (as perceived by voting shareholders) is lower, particularly with respect to executive pay. To examine this hypothesis, in Panel A of Table 3 we use four different measures of management credibility. The first is a summary measure of the perceived quality of the firm's compensation practices: an indicator equal to one if the company received more than $20 \%$ of votes against their compensation plan at the (contemporaneous) 2011 SOP vote (High Votes Against SOP, equal to one at $13.8 \%$ of the sample firms). Ertimur et al. (2013) show that votes against the SOP proposal are higher at firms with a perceived past disconnect between performance and CEO pay and with a negative recommendation from the proxy advisors, which, in turn, single out firms with excessive perks and firms with certain provisions in their severance agreements (e.g. excise tax gross-ups). If shareholders view an annual SOP vote as a means to impose greater accountability, support for the triennial frequency recommended by management should be lower when there are concerns with the quality of the current compensation practices (as proxied for by higher SOP voting dissent). 
The second and third measures capture shareholders' confidence in management as revealed by past shareholder votes. High Votes Withheld from Directors is an indicator variable equal to one if the maximum votes withheld from directors over the 2008-2010 annual meetings exceed $20 \%$, a level viewed as expression of substantial dissatisfaction with board performance (Del Guercio et al. 2008). Frequent reasons for high votes withheld from directors are the board's failure to implement shareholder proposals, lack of independence of some board members, low attendance of board meetings and, particularly in recent years, perceived failures in monitoring executive pay (Del Guercio et al. 2008; Cai et al. 2009; Fischer et al. 2009; Ertimur et al. 2011). The indicator is equal to one for $41.3 \%$ of the sample firms, reflecting the increasing use of "withhold" votes by activists in recent years. High Votes Against Mgmt Proposals is an indicator equal to one if the maximum votes cast against management proposals over the $2008-2010$ period is more than $20 \%$, a relatively rare occurrence (only $4.1 \%$ of the sample firms). A significant portion of management proposals are proposals to adopt or renew an equity incentive plan, with negative votes usually triggered by concerns about excessive dilution and certain controversial features, such as repricing, reload and evergreen provisions (Thomas and Martin 2000; Morgan and Poulsen 2001; Morgan, Poulsen and Wolf 2006). In brief, both measures capture shareholders' past skepticism about management actions, also (but not only) with respect to executive pay. ${ }^{23}$ We expect less shareholder support for management recommendations in firms with this type of history.

While the three measures above are based on shareholder votes, our fourth and final variable is a measure of management credibility based on management disclosures to investors: Mgmt

\footnotetext{
${ }^{23}$ We obtain similar results when we redefine both variables to capture executive pay concerns only. In particular, we redefine High Votes Against Mgmt Proposals as an indicator variable equal to one if the maximum votes cast against compensation-related management proposals over the $2008-2010$ period is more than $20 \%$, and we redefine High Votes Withheld from Directors as an indicator variable equal to one if the maximum votes withheld from compensation committee members over the 2008-2010 annual meetings exceeds $20 \%$. Note that the latter variable is a noisy proxy for compensation-related votes withheld, since votes may be withheld from a director who sits on the compensation committee member for reasons unrelated to executive pay.
} 
Forecast Error, the average absolute annual management forecast error in 2010. Since not all companies issue such a forecast, we also include an indicator denoting a forecast issuer (Mgmt Issues Forecast). In line with the literature on management forecasts (e.g. Hillary and Hsu 2011; Lee, Matsunaga and Park 2012), we conjecture that management issuing less accurate earnings forecasts (relative to the ex post reported earnings) will be perceived as less credible, leading to lower support for management triennial recommendations.

To empirically test our predictions, in Table 3 we perform a multivariate analysis of the voting outcome for the sub-sample of companies that recommended triennial SOP frequencies. ${ }^{24}$ As in Table 2, the dependent variable is SWOP Votes for Triennial. In Panel A, Model (1), we include the same variables as in Table 2. Then, in Models (2)-(5) we add our proxies for management credibility. Consistent with our predictions, we find that shareholders are less inclined to follow management recommendation for triennial SOP votes when perceived management credibility is lower. All four of our measures (High Votes Against SOP, High Votes Withheld from Directors, High Votes Against Mgmt Proposals and Mgmt Forecast Error) are associated with lower voting support for triennial SOP frequencies, also when included at the same time (Model (6)).

Appendix 1 indicates that one of the key arguments in favor of a triennial vote is that it is better aligned with the long-term horizon of the compensation plan. In Panel B of Table 3, we examine whether shareholders are more likely to follow management recommendations for triennial SOP votes when the horizon of the compensation plan is longer, as proxied for by three sets of variables. First, we include the measure of CEO Pay Duration developed by Gopalan et al.

\footnotetext{
${ }^{24}$ We obtain similar results when the analysis is performed on the full sample with interaction terms between Mgmt SWOP Rec: Triennial and the expected determinants of voting outcome, a design essentially equivalent to running separate regression for annual and triennial recommendation firms. We present the results for the subset of firms with triennial recommendations for ease of exposition and because the analysis of the case of annual recommendations is not interesting (since essentially both insiders and almost all investors vote for annual, with little variation in voting outcomes).
} 
(2012), namely, a weighted average duration of four components of pay (salary, bonus, restricted stock and options), with salary and bonus being assigned a vesting period of zero. ${ }^{25}$ Since we do not have immediate access to the data required to compute a firm-specific measure (e.g. detailed vesting schedules) we use the industry average CEO pay duration (based on the Fama-French 48 industries' classification) reported in Table 3 of Gopalan et al. (2012), which ranges between 0.7 and 2.1 years. Second, to proxy for firm-specific CEO pay duration, we include Book-To-Market Ratio, $R \& D /$ Total Assets and Volatility, reflecting Gopalan et al.'s (2012) evidence that CEO pay duration is longer in firms with more growth opportunities, greater R\&D intensity and lower risk. Finally, since equity pay tends to have higher duration than cash pay, we include the percentage of equity pay in total CEO pay (CEO Equity Pay Ratio).

As shown in Panel B, only one of these proxies (CEO Equity Pay Ratio) is significantly related to voting support for triennial SOP votes, but with the opposite sign (suggesting perhaps that shareholders are less willing to give up monitoring power when equity pay is a significant part of compensation) ${ }^{26}$ Hence, the horizon of the compensation plan does not seem to play a role in shareholders' voting decision on the frequency of future SOP votes.

In summary, our analyses suggest that management recommendations have a significant influence on shareholder votes and that this influence is a function of management credibility with shareholders and concerns with the quality of the compensation plan.

\section{Say on Pay frequency choice and firms' responsiveness to Say on Pay votes}

\subsection{Firms' choice of SOP frequency}

\footnotetext{
${ }^{25}$ Gopalan et al. (2012) also use an alternative duration measure that takes into account grants of prior years and uses pay-performance sensitivity as the weight to calculate duration (instead of the dollar value of the grants). All our results are robust to the use of this alternative measure.

${ }^{26}$ In unreported tests we also replace our proxies with an indicator for firms in the top quartile of the distribution of each of the variables. The coefficient is not significant.
} 
The Dodd-Frank Act mandated that firms disclose their decision with respect to the frequency of future SOP votes by filing an $8-\mathrm{K}$ within 150 days of the SWOP vote. We collect this information from $8-\mathrm{K}$ filings for 1,346 of our 1,365 sample firms (19 firms merged or delisted prior to disclosing their adoption decision).

Table 4 reports the distribution of firms' decisions by management recommendations and yields two insights. First, while recommended in $61.6 \%$ of the cases (Table 1), the annual frequency is adopted by $90.7 \%$ of the firms $(1,221$ out of 1,346$)$, with most of the remaining firms adopting a triennial frequency. Second, in all but 12 cases the adopted frequency is the one that won most votes by shareholders, thereby explaining the widespread adoption of the annual frequency. ${ }^{27}$ This high rate of responsiveness to a non-binding shareholder vote is unusual: the rate of adoption of non-binding governance related and compensation-related shareholder proposals approved by a majority vote is about $30-40 \%$, depending on the time period (Ertimur et al. 2010, 2011). More recently, Ertimur et al. (2013) report that 55\% of the firms with a negative recommendation on SOP from ISS respond by making changes to their compensation plan.

\subsection{Firm's responsiveness to SOP votes: Does a triennial vote reduce firms' responsiveness?}

Supporters of annual SOP votes argued that a triennial frequency would reduce accountability and protect firms from scrutiny over excessive pay packages (Appendix 2). In this section, we provide more direct evidence on this question. To do so, we exploit the fact that in addition to the vote on the frequency of future SOP votes, in 2011 firms faced the first mandatory SOP vote and were requested to disclose in the 2012 proxy statement if and how they took into account the 2011 SOP vote. Hence, we can examine whether triennial adopters - facing the next SOP vote in 2014

\footnotetext{
${ }^{27}$ All of the 12 "off-diagonal" cases involve firms that recommended a triennial frequency. Ten of them adopted an annual frequency, following the choice of the majority of peer firms (and their shareholders), even though the triennial option had won the highest number of shareholder votes. The other two firms adopted a triennial frequency (the management's recommended frequency) in spite of losing the vote.
} 
only - were less likely to make changes to their compensation practices after substantial shareholder opposition voiced at the 2011 SOP vote relative to annual adopters subject to the same opposition but already facing the next SOP vote in 2012 .

For this purpose, we condition our sample on companies that received a SOP Against recommendation by ISS in 2011. Ertimur et al. (2013) document a strong association between negative ISS recommendations and shareholder votes against the SOP proposal in 2011, with $26.8 \%$ more votes against SOP when ISS issues a negative recommendation. Hence, after the vote, these firms were under pressure to engage with shareholders and make changes to their compensation plans. To increase the power of the test, we expand our sample to cover all companies included in the Russell 3000 index (the full universe covered by the Voting Analytics dataset). The resulting sample consists of 273 firms with an ISS against recommendation (203 annual adopters, 70 triennial adopters), averaging $29.8 \%$ votes against the SOP proposal. For each of these firms, we read the 2012 proxy filing and create an indicator equal to one if the firm discloses compensation changes made in response to the 2011 SOP vote (often in consultation with their institutional investors; see Appendix 3 for examples of these disclosures).

Table 5 summarizes the results of our analysis. Of the 203 companies with annual frequency (and thus facing another SOP vote in 2012), 67.5\% made changes to their compensation plans in response to the 2011 vote. In stark contrast, of the 70 firms adopting a triennial frequency (and thus facing another SOP vote only in 2014), only $14.3 \%$ of companies changed their compensation practices in response to the 2011 SOP vote. ${ }^{28}$ The differences are statistically significant at the $1 \%$ level $(\mathrm{p}$-value $=0.000$, untabulated $)$.

\footnotetext{
${ }^{28}$ If this difference merely reflected firm characteristics (e.g. triennial adopters are firms that recommended triennial because they are less responsive in the first place) rather than the effect of the adopted frequency, we should observe similarly low responsiveness also for the subset of 70 annual adopters that had recommended triennial. Instead, the
} 
This evidence suggests that a less frequent shareholder vote results in lower responsiveness to shareholder concerns, consistent with arguments brought forward by proponents of annual SOP votes. We consider two alternative explanations. The first one is that the compensation changes made by annual adopters are immaterial and artificially inflate the rate of responsiveness relative to the triennial firms. However, annual adopters reporting changes to their compensation plan experience a large decrease in votes against SOP (from 39.6\% in 2011 to $19.6 \%$ in 2012, on average) suggesting that these changes are perceived by voting shareholders as an adequate and material response to the 2011 vote. Also, our reading of the disclosed compensation changes suggests that, if anything, the changes made by annual adopters tend to be more salient and to involve multiple features of the compensation plan. ${ }^{29}$

A second potential explanation is that the lower responsiveness by triennial adopters is due to the lower SOP voting dissent these firms experience relative to annual adopters: $16.0 \%$ versus $34.5 \% .{ }^{30}$ Previous studies suggest that firms' responsiveness to shareholder votes is a function of the voting outcome (e.g. Ertimur et al. 2010), also in the case of SOP proposals (Ertimur et al. 2013). ${ }^{31}$ Hence, the lower responsiveness of triennial firms may reflect the lower SOP voting dissent rather than the chosen SOP frequency.

rate of compensation changes in this sub-sample is $64.3 \%$, significantly higher (at $1 \%$ level) than for the sample of triennial adopters.

${ }^{29}$ We find that these changes cover a variety of issues. The most frequent changes are the introduction of performance-based vesting conditions in equity grants, the toughening of performance goals in short- and long-term incentive plans, the elimination or substantial reduction of certain perks (e.g. personal aircraft use) and tax gross-ups on perks (e.g. tax gross-ups upon the vesting of executives' outstanding restricted stock awards), and the removal of modified single-trigger provisions and excise tax gross-ups from change-in-control severance agreements.

${ }^{30}$ The difference is partly driven by the higher percentage of votes controlled by insiders in triennial adopters (33.6\%) versus annual adopters $(10.1 \%)$. When we re-compute SOP voting dissent in terms of non-insider votes, the difference, while still relevant, is somewhat lower: the percentage of non-insider votes cast against SOP at triennial adopters is $26.7 \%$, versus $38.4 \%$ at annual adopters.

${ }^{31}$ The relation between voting outcome and subsequent responsiveness is also evident in our data: in the sample of firms disclosing compensation changes, \% SOP Voting Dissent 2011 is $38.4 \%$. The corresponding figure for firms with no compensation changes (untabulated) is $19.7 \%$. 
To examine this possibility we restrict the sample of annual adopters to firms with $\%$ SOP Voting Dissent 2011 below the highest dissent observed at triennial adopters (43\%), basically comparing firms within the same range of \% SOP Voting Dissent 2011. The observed differences in the rate of responsiveness, while slightly lower, remain substantial: $58.7 \%$ of the annual adopters made compensation changes in response to the 2011 vote, versus only $14.3 \%$ of the triennial firms (the difference is statistically significant at the $1 \%$ level).

Note, however, that, even after this adjustment, triennial adopters continue to have lower \% SOP Voting Dissent 2011 relative to annual adopters (16.0\% versus $28.5 \%)$. Hence, in the last column of Table 5, we further restrict the sample of annual adopters to firms with less than $30 \%$ in terms of \% SOP Voting Dissent 2011, making the samples even more similar in terms of SOP dissent $(16.0 \%$ versus $20.3 \%)$. The threshold is particularly interesting because ISS stated it would issue another negative SOP recommendation in 2012 and withhold recommendation against compensation committee members if companies receiving less than $70 \%$ voting support in 2011 failed to adequately address compensation concerns. Ertimur et al. (2013) document a significant drop in firms' responsiveness to SOP votes below this threshold. Consistent with their evidence, as shown in the last column, the rate of responsiveness by annual adopters is lower below this threshold, but still more than twice as high as for triennial adopters: $31.9 \%$ of the annual adopters made changes to their compensation plans in response to the 2011 vote, versus only $14.3 \%$ of the triennial firms (the difference remains statistically significant; $p$-value $=0.012$ ).

In Table 6 we conduct a multivariate test through a logistic regression where the dependent variable is an indicator equal to one (zero) if the firm discloses (does not disclose) compensation changes in response to the SOP vote. In Model (1) we include as independent variable an indicator, Triennial Adopter, equal to one (zero) if the firm adopted a triennial (annual) frequency. Next, we 
add first the SOP voting dissent (Model (2)) and then a series of firm characteristics that may capture a firm's responsiveness to shareholder pressure, such as insider ownership, institutional ownership, size and performance (Model (3)). Across the three models, the coefficient on the indicator for triennial adopters is negative and significant. As for economic significance, in Model (3) the coefficient implies that (holding all other variables at their median values) the predicted likelihood of a post-SOP compensation change is $62 \%$ for annual adopters versus $39 \%$ for triennial adopters. With respect to the other control variables, consistent with prior research, responsiveness is higher in firms with greater shareholder pressure (higher SOP voting dissent, higher institutional ownership) and worse performance. Taken together, the evidence presented in Tables 5 and 6 suggests that a less frequent vote is associated with lower responsiveness to shareholder concerns, echoing a similar finding in Faleye (2007) that firms with classified boards (another form of less frequent scrutiny) are less likely to implement shareholder-approved shareholder proposals.

\section{Determinants of management recommendations on the frequency of SOP}

While the focus of our study is to estimate the extent of management influence on shareholder votes, its determinants and its effect on responsiveness to SOP votes, to conclude our investigation we also examine the determinants of management recommendations on the frequency of SOP votes. In addition to being interesting in itself, this analysis may help us better interpret the findings in the previous sections. For this purpose, we estimate a logistic regression where the dependent variable, Triennial, is equal to one if management recommends a biennial or triennial frequency, and zero if management recommends annual (we exclude the 40 cases of no management recommendations). We predict that management will choose its recommendation based on the perceived costs and benefits from the various alternatives, while also taking into 
account the expected voting outcome. Below we elaborate on the specific predictions and the corresponding variables used in the empirical tests.

\subsection{Ownership structure and other financial characteristics}

As a starting point, we conjecture that, all else being equal, management will take into account the expected voting outcome when making its recommendation. As noted in the Introduction, a number of studies document management's attempts to influence the voting process (see footnote 7), suggesting that management is concerned with the voting outcome. While the frequency vote is advisory, Ertimur et al. (2010) find that firms are under increasing pressure to adopt non-binding resolutions supported by a majority of shareholders, with Levit and Malenko (2011) studying analytically when adopting such resolutions may be optimal. Ignoring a shareholder vote is one of the most common reasons behind a negative recommendation by ISS against directors up for election (ISS 2013)-resulting in high votes withheld from directors (Cai et al. 2009) - and it has been found to affect directors' reputation in the director labor market (Ertimur et al. 2010). In this specific context, ignoring shareholders' preferences may also lead to more negative votes on the SOP proposal itself, and result in future shareholder proposals requesting to adopt the frequency preferred by shareholders. Hence, given the costs associated with losing the vote, all else being equal, we predict that management is more likely to recommend triennial when there is a higher chance of winning the vote. ${ }^{32}$

In turn, this chance will depend, among other things, on the ownership structure of the company and the corresponding voting rights. In particular, we expect a higher likelihood of triennial recommendations when the \% Votes Controlled by Insiders is higher, while we expect a lower likelihood of triennial recommendations when \% Institutional Ownership is higher (given

\footnotetext{
${ }^{32}$ Consistent with this prediction, law firms advised their corporate clients against recommending a triennial frequency if many of its institutional investors were known to favor an annual frequency and, thus, the likelihood of winning the vote was low (Kramer Levin Naftalis \& Frankel 2011).
} 
the support for the annual frequency announced by many institutional investors ahead of the proxy season; see footnote 9). As for \% Non-Inst. Block Ownership, while the preferences of these noninstitutional block-holders may be heterogeneous, because of their substantial equity in the firm they may not need an additional monitoring tool (the annual SOP vote) and may prefer instead to keep a good relation with management for more important decisions (e.g. acquisitions, share repurchases.) and, thus, follow management recommendation. Hence, we predict a higher likelihood of triennial recommendations in firms with higher \% Non-Inst. Block Ownership.

While these variables are proxies for the expected voting outcome, management perception of the expected voting outcome may matter as well. A growing body of research has documented the effect of CEO overconfidence on financial and investment policies, governance structures and disclosure and reporting choices. ${ }^{33}$ Table 1 suggests that the triennial option wins the vote in only $25.8 \%$ (117 out of 452 ) of the cases where management recommends triennial, leading us to examine whether CEO "overconfidence" (in their ability to influence shareholder votes) may have increased their propensity to recommend a triennial frequency (despite the known support for annual SOP votes by many institutional investors). Hence, we include an indicator for Overconfident CEO (equal to one if a CEO is classified as overconfident according to the option exercise-based measure used in Campbell, Galleyer, Johnson, Rutherford and Tanley 2011).

Management perception of the expected voting outcome may have changed as the proxy season progressed and shareholders' support for annual frequency became evident. To capture this possibility (supported by the pattern in Figure 1) we include an indicator equal to one for meetings taking place after March 31, 2011 (Post March 2011). We also include an indicator for firms where a SOP vote had already taken place before such votes became mandatory in 2011 (Prior

\footnotetext{
${ }^{33}$ Examples of these studies include Ahmed and Duellman (2013), Gervais, Heaton and Odean (2011), Goel and Thakor (2008), Hilary and Hsu (2011), Hribar and Yang (2013), Libby and Rennekamp (2012), Malmendier and Tate (2005, 2008), Malmendier, Tate and Yan (2011) and Schrand and Zechman (2012).
} 
SOP Vote), either because a SOP vote was required as a condition to receive TARP funding or (more rarely) because they voluntarily adopted SOP. Presumably, these firms have already incurred the costs associated with a SOP vote and their shareholders have become accustomed to an annual vote. Hence, we expect these firms to be less likely to recommend a triennial frequency.

Finally, we control for size $(\ln (M V$ Equity $))$ and operating and stock performance (Return on Assets, Abnormal Returns). Management may expect shareholders to be more willing to accept a triennial frequency (essentially giving up some monitoring power) if performance has been positive. As for size, the effect is unclear. Voting support for management is generally higher in larger firms (e.g. Ertimur et al. 2010) but larger firms may also incur greater reputation costs for recommending a frequency opposed by the most vocal activists.

\subsection{Compensation and governance characteristics}

Our second set of predicted determinants of management recommendations includes variables capturing the characteristics of the compensation plan and the governance structure. To capture the horizon of the compensation plan, similar to Section 3.3, we use CEO Pay Duration, Book-ToMarket Ratio, R\&D/Total Assets, Volatility and CEO Equity Pay Ratio. If management recommends triennial because of the long-term nature of the compensation plan, we expect a positive association between the likelihood of triennial recommendations and our proxies for the long-term nature of the compensation plans.

Alternatively, management may recommend triennial SOP votes to reduce the level of scrutiny over compensation. To examine this possibility, we first include the level of CEO Total Pay and then split it into a predicted component (CEO Expected Pay) and a residual component (CEO Residual Pay), the latter capturing CEO pay in excess of the amount predicted based on economic determinants such as operating and stock performance, book-to-market, and sales (following Core, 
Guay and Larcker 2008). If avoiding scrutiny is a reason behind triennial recommendations, we would expect a positive coefficient on CEO Total Pay and, in particular, on CEO Residual Pay.

Finally, we control for governance characteristics by including two standard measures of board independence (CEO-Chairman Duality and \% Independent Directors), an indicator for Classified Board and an indicator for Majority Voting as director election standard. We expect firms with a classified board to be more likely to recommend a triennial SOP vote. Since firms subject to a majority voting standard may be more concerned about votes withheld from directors (Ertimur, Ferri and Oesch 2012) we expect them to prefer an annual SOP vote to avoid the risk of compensation-related vote-no campaigns in the off years.

\subsection{Results}

Table 7 and 8 present the results of univariate and multivariate analyses. Since firms recommending triennial are smaller and size is correlated with many other firm characteristics (e.g. CEO total pay), below we comment only on the multivariate tests, and report the univariate tests mostly for descriptive purposes.

Consistent with most of our predictions, Table 8, Panel A, indicates that firms with a larger percentage of votes controlled by insiders and non-institutional block-holders, better performing firms (though only Return on Assets is significant) and firms with overconfident CEOs are more likely to recommend triennial, whereas larger firms, firms with a Prior SOP Vote, and firms with greater institutional ownership are more likely to recommend an annual SOP vote. ${ }^{34}$ The likelihood of triennial recommendations is significantly lower after March 2011. Interestingly, when we runseparate regressions for the periods before and after March $31^{\text {st }}$ (untabulated), Overconfident CEO is significant only in the period prior to March $31^{\text {st }}$, consistent with the idea that over-confidence is

\footnotetext{
34 The sample includes 1,308 observations: that is, the 1,365 observations in Table 1 minus 40 cases of no management recommendations and 17 observations lost due to lack of required data to compute the CEO overconfidence measure.
} 
one of the reasons behind the high frequency of triennial recommendations in the early part of the proxy season (Fig.1). In terms of economic significance, we find that, for most variables (\% Votes Controlled by Insiders, Return on Assets, \% Institutional Ownership, Overconfident CEO and $\ln (M V$ Equity)), moving from the first to the third quartile of the sample distribution (while keeping all the other variables at the median) changes the likelihood of a triennial recommendation by about $4-6 \%$ (e.g. from $\sim 27 \%$ to $\sim 31 \%$ ). Consistent with Figure 1, the likelihood of a triennial recommendation drops from $53 \%$ to $28 \%$ (holding other variables at their median) when Post March 2011 is equal to one. ${ }^{35}$

In Model (2) we examine in more detail the relation between institutional ownership and the recommendation decision by splitting the \% Institutional Ownership variable into the percentage of equity held by institutional investors In Favor of Annual, In Favor of Triennial or With No Stated Preference. We find that firms with more (equity held by) institutional investors In Favor of Annual are less likely to recommend triennial, while those with more institutional investors In Favor of Triennial are more likely to recommend triennial (though the coefficient is not significant). As for the institutional investors With No Stated Preference, the negative coefficient suggests that management expected most of them to support the annual frequency.

In Panel B, we add the compensation and governance variables. Using our proxies for the horizon of the compensation plan, we do not find that firms with a longer-term compensation plan are more likely to recommend triennial (Model (1)). In unreported tests, we also repeat the analysis for meetings occurring between January and March 2011, on the ground that perhaps economic factors played a stronger role at the beginning of the proxy season and that firms favoring triennial may have stopped recommending it once the investors' support for annual SOP votes became

\footnotetext{
${ }^{35}$ In unreported tests, we find that firms with an annual meeting after March 31 are generally similar to firms with an annual meeting before March 31 in terms of the firm characteristics included in Table 8.
} 
apparent. However, our proxies for the horizon of the compensation plan are insignificant even in the January-March 2011 period. In contrast, we do find that triennial recommendations are more likely for firms with higher CEO Total Pay (Model (2)) and, in particular, for firms with higher CEO Residual Pay, consistent with a desire to avoid the more frequent scrutiny associated with annual votes. However, the economic significance of this effect is relatively small: an increase in CEO Residual Pay from the first to the third quartile of the sample distribution (while keeping all the other variables at the median) increases the likelihood of a triennial recommendation by about $1.7 \%$ (e.g. from $27.3 \%$ to $29.0 \%$ ). As for the governance variables, consistent with our predictions, firms with classified boards (majority voting) are more (less) likely to recommend triennial SOP votes (the effect on the likelihood of triennial recommendations is about 5\%). In unreported tests we also include industry fixed effects and the ratio of industry peers recommending triennial. The latter coefficient is not significant and our inferences remain unchanged.

Overall, our analyses suggest that firms recommended triennial when insiders controlled more votes (hence, increasing the chance of winning the vote) and when CEO pay was higher, while the horizon of the compensation plan did not play a role, contrary to firms' statements in support of triennial SOP votes (Appendix 1). 


\section{Conclusions}

The Dodd-Frank Act mandated firms to hold an advisory vote on the frequency of future SOP votes in 2011, giving shareholders a choice between an annual, a biennial and a triennial. While proxy advisors supported an annual frequency, management recommendations varied across companies, a unique feature which we exploit to provide an estimate of the influence of management recommendations and examine its determinants and consequences.

Using a sample of S\&P 1500 firms, we find that management recommendation for a given frequency is associated with $25.9 \%$ more voting support for that frequency, a figure close to estimates of the influence of proxy advisors in prior studies. Additional tests suggest that the association is likely to capture a causal effect. Management credibility with shareholders (as reflected by past votes) is a key determinant of management influence on voting outcomes.

While the votes were non-binding, virtually all companies decided to adopt the SOP frequency that garnered most votes. Interestingly, firms that adopted a triennial frequency (because shareholders trusted management recommendation and voted for triennial)—and, thus, facing the next SOP vote in 2014-were significantly less likely to make changes to their compensation practices in response to adverse SOP votes relative to firms that adopted an annual frequency (and, thus, faced the next SOP vote in 2012). The result is not attributable to differences in firm characteristics or voting outcomes, and is consistent with the notion that a less frequent vote reduces management accountability. It also suggests that management may have used its significant influence over shareholder votes to reduce scrutiny over its compensation via a less frequent SOP vote. Our results contribute to the literature on shareholder voting and executive pay and call for more research on the influence of management on shareholder votes. 


\section{References}

Aggarwal, R., P. Saffi and J. Sturgess, 2012. The Role of Institutional Investors in Voting: Evidence from the Securities Lending Market. Working Paper, Georgetown University.

Ahmed, A. and S. Duellmann, 2013. Managerial Overconfidence and Accounting Conservatism. Journal of Accounting Research 51, 1-30.

Alexander, C., M. Chen, D. Seppi and C. Spatt, 2010. Interim News and the Role of Proxy Voting Advice. Review of Financial Studies 23, 4419-4454.

Armstrong, C., I. Gow and D. Larcker, 2013. The Efficacy of Shareholder Voting: Evidence from Equity Compensation Plans, Journal of Accounting Research, forthcoming.

Bagiski S., S. Clinton and S. McGuire, 2013. Forward-Looking Voluntary Disclosure In Proxy Contests. Working Paper, University of Georgia.

Bainbridge S., 2006. The Case for Limited Shareholder Voting Rights. UCLA Law Review $53,601-636$.

Bebchuk, L. A., 2005. The Case for Increasing Shareholder Power. Harvard Law Review 118, 835-914.

Bebchuk, L.A. and A. Cohen, 2005. The Costs of Entrenched Boards. Journal of Financial Economics 78, 409-433.

Bebchuk, L. A., A. Cohen and C. Y. Wang, 2011. Staggered Boards and Wealth of Shareholders: Evidence from Two Natural Experiments. Working Paper Harvard Law School.

Bebchuk, L. A. and J. M. Fried, 2004. Pay Without Performance: The Unfulfilled Promise of Executive Compensation, Harvard University Press.

Bebchuk, L. A. and E. Kamar, 2010. Bundling and Entrenchment. Harvard Law Review 123, 1551-1595.

Becker, B., D. B. Bergstresser and G. Subramanian, 2013. Does Shareholder Proxy Access Improve Firm Value? Evidence from the Business Roundtable Challenge. Journal of Law and Economics 56, 127-160.

Bethel, J. E. and S. Gillan, 2002. The Impact of the Institutional and Regulatory Environment on Shareholder Voting. Financial Management 31, 29-54.

Bethel, J. E., G. Hu and Q. Wang, 2009. The Market for Shareholder Voting Rights around Mergers and Acquisitions: Evidence from Institutional Daily Trading and Voting. Journal of Corporate Finance 15, 129-145. 
Brickley, J., R. Lease, and C. Smith Jr, 1988. Ownership Structure and Voting on Antitakeover Amendments. Journal of Financial Economics 20, 267-291.

Bushee B., 1998. The Influence of Institutional Investors on Myopic R\&D Investment Behavior. The Accounting Review 73, 305-333.

Cai, J., J. Garner and R. Walkling, 2009. Electing Directors. Journal of Finance 64, 2389-2421.

Cai, J. and R. Walkling, 2011. Shareholders' Say on Pay: Does it Create Value? Journal of Financial and Quantitative Analysis 46, 299-339.

Campbell, T., M. Galleyer, S. Johnson, J. Rutherford and B. Tanley, 2011. CEO Optimism and Forced Turnover. Journal of Financial Economics 101, 695-712.

Christoffersen, S. E. K., C. C. Geczy, D. K. Musto and A. V. Reed, 2007. Vote Trading and Information Aggregation. Journal of Finance, 62, 2897-2929.

Choi, S., J. Fisch and M. Kahan, 2010. The Power of Proxy Advisors: Myth or Reality? Emory Law Journal 59, 101-151.

Cohn, J., S. Gillan and J. Hartzell, 2013. On Enhancing Shareholder Control: A (Dodd-) Frank Assessment of Proxy Access. Journal of Finance, forthcoming.

Core, J. E., W. Guay and D. F. Larcker, 2008. The Power of the Pen and Executive Compensation. Journal of Financial Economics 88, 1-25.

Cuñat, V., M. Gine and M. Guadalupe, 2012. The Vote is Cast: The Effect of Corporate Governance on Shareholder Value. Journal of Finance 67, 1943-1977.

DeAngelo, L., 1988. Managerial Competition, Information Costs, and Corporate Governance: The Use of Accounting Performance Measures in Proxy Contests. Journal of Accounting and Economics 10, 3-36.

Davis, G. and E. Kim, 2007. Business ties and proxy voting by mutual funds. Journal of Financial Economics 85, 552-570.

Del Guercio, D., L. Seery and T. Woidtke, 2008. Do Boards Pay Attention When Institutional Investors "Just Vote No"? Journal of Financial Economics 90, 84-103.

Dimitrov V. and P.C. Jain, 2011. It's Showtime: Do Managers Report Better News Before Annual Shareholder Meetings? Journal of Accounting Research 49, 1193-1221.

Ertimur, Y., F. Ferri and D. Maber, 2012. Reputation Penalties for Poor Monitoring of Executive Pay: Evidence from Option Backdating. Journal of Financial Economics 104, 118-144. 
Ertimur, Y., F. Ferri and V. Muslu, 2011. Shareholder Activism and CEO Pay. Review of Financial Studies 24, 535-592.

Ertimur, Y., F. Ferri and D. Oesch, 2012, Does the Director Election System Matter? Evidence from Majority Voting. Working Paper, Columbia University.

Ertimur, Y., F. Ferri and D. Oesch, 2013, Shareholder Votes and Proxy Advisors - Evidence from Say on Pay. Journal of Accounting Research, forthcoming.

Ertimur, Y., F. Ferri and S. Stubben, 2010. Board of Directors' Responsiveness to Shareholders: Evidence from Shareholder Proposals. Journal of Corporate Finance 16, 53-72.

Faleye O., 2007. Classified Boards, Firm Value, and Managerial Entrenchment. Journal of Financial Economics 83, 501-529.

Ferri, F., 2012. 'Low-Cost' Shareholder Activism: A Review of the Evidence. Research Handbook on the Economics of Corporate Law, Ch.11, Claire Hill \& Brett McDonnell, eds., Elgar Publishers.

Ferri, F. and D. Maber, 2013. Say on Pay Votes and CEO Compensation: Evidence from the UK. Review of Finance 17, 527-563.

Ferri, F. and T. Sandino, 2009. The Impact of Shareholder Activism on Financial Reporting and Compensation: The Case of Employee Stock Options Expensing. The Accounting Review 84, 433-466.

Fischer, P., J. Gramlich, B. Miller and H. White, 2009. Investor Perceptions of Board Performance: Evidence from Uncontested Director Elections. Journal of Accounting and Economics 48, 172-189.

Gervais, S., J. B. Heaton, and T. Odean, 2011. Overconfidence, Compensation Contracts, and Capital Budgeting. Journal of Finance 66, 1735-1777.

Gillan, S. and L. Starks, 2000. Corporate Governance Proposals and Shareholder Activism: The Role of Institutional Investors. Journal of Financial Economics 57, 275-305.

Goel, A. and A. Thakor, 2008. Overconfidence, CEO selection, and Corporate Governance. Journal of Finance 63, 2737-2784.

Gopalan, R., T. Milbourn, F. Song and A. Thakor, 2012. The Optimal Duration of Executive Compensation: Theory and Evidence, Journal of Finance (forthcoming).

Glass Lewis \& Co., 2011. Proxy Paper Guidelines 2011 Proxy Season.

Hauder E., 2011. Shareholders' Position on Say on Pay, available at http://say-onpay.com/shareholder-positions/ 
Hilary, G. and C. Hsu, 2011. Endogenous Overconfidence in Managerial Forecasts. Journal of Accounting and Economics 51, 300-313.

Hribar, P., and H. Yang 2013. CEO Overconfidence and Management Forecasting. University of Iowa and University of Pennsylvania, Working paper

Hu, H. and B. Black, 2007. Hedge Funds, Insiders and the Decoupling of Economic and Voting Ownership: Empty Voting and Hidden (Morphable) Ownership. Journal of Corporate Finance $13,343-367$.

ISS, Institutional Shareholder Services, 2011. U.S. Proxy Voting Guidelines Summary

ISS, Institutional Shareholder Services, 2013. U.S. Proxy Voting Guidelines Summary.

Kahan M. and E.B. Rock, 2011. The Insignificance of Proxy Access, Virginia Law Review 97, $1347-1434$.

Kramer Levin Naftalis \& Frankel LLP, 2011. "Say on pay" in the Spotlight, available on the company's website (www.kramerlevin.com)

Larcker D. F., A. L. McCall and G. Ormazabal, 2012. The Economic Consequences of Proxy Advisor Say-on-Pay Voting Policies. Working Paper, Stanford University.

Larcker D. F., A. L. McCall and G. Ormazabal, 2013. Proxy Advisory Firms and Stock Option Repricing. Journal of Accounting and Economics 56, 149-169.

Larcker, D., G. Ormazabal and D. Taylor, 2011. The Market Reaction to Corporate Governance Regulation, Journal of Financial Economics 101, 431-448.

Lee, S., S. M. Matsunaga and C. W. Park, 2012, Management Forecast Accuracy and CEO Turnover. The Accounting Review 87, 2095-2122.

Levit, D. and N. Malenko, 2011. Nonbinding Voting for Shareholder Proposals, Journal of Finance 66, 1579-1614.

Libby, R. and Rennekamp, K., 2012. Self-Serving Attribution Bias, Overconfidence and the Issuance of Management Forecasts. Journal of Accounting Research 50, 197-231.

Listokin, Y., 2009. Corporate Voting vs. Market Price Setting. American Law and Economics Review 11, 608-635.

Listokin, Y., 2010. Management Always Wins the Close Ones. American Law and Economics Review 10, 159-184. 
Malmendier, U., and G. Tate, 2005. CEO Overconfidence and Corporate Investment. Journal of Finance 60, 2660-2700.

Malmendier, U. and G. Tate, 2008. Who Makes Acquisitions? CEO Overconfidence and the Market's Reaction. Journal of Financial Economics 89, 20-43.

Malmendier, U., G. Tate and J. Yan, 2011. Overconfidence and Early-life Experiences: The Effect of Managerial Traits on Corporate Financial Policies. Journal of Finance 66, 1687-1733.

Morgan, A. and A. Poulsen, 2001. Linking Pay to Performance - Compensation Proposals in the S\&P 500, Journal of Financial Economics 62, 489-523.

Morgan, A., A. Poulsen and J. Wolf, 2006. The Evolution of Shareholder Voting for Executive Compensation Schemes. Journal of Corporate Finance 12, 715-737.

Ng J., I. Tuna and R. Verdi, 2013. Management Forecast Credibility and Underreaction to News, Review of Accounting Studies 18, 956-986.

Rogers, J.L. and P.C. Stocken, 2005. Credibility of Management Forecasts. The Accounting Review 80, 1233-1260.

Schrand, C. and S. Zechman, 2012. Executive Overconfidence and the Slippery Slope to Fraud. Journal of Accounting and Economics 53, 311-329.

SEC, Securities and Exchange Commission, 2010. Concept Release No. 34-62495, available at: http://www.sec.gov/rules/concept/2010/34-62495.pdf

Thomas, R. and Martin, K., 2000. Determinants of Shareholder Voting on Stock Option Plans, Wake Forest Law Review 35, 31-82.

Wall Street Journal (WSJ), 2013. Getting Out the (Proxy) Vote, March 4, 2013.

Young, P., J. Millar and G. Glezen, 1993. Trading Volume, Management Solicitation, and Shareholder Voting, Journal of Financial Economics 33, 57-71. 


\section{Appendix 1 Management recommendations on the frequency of Say-on-Pay votes}

\section{Examples of management recommendations in favor of triennial SOP votes}

"The design of the compensation program is stable year over year and supports the following core business strategies of ExxonMobil: long-term growth in shareholder value; risk management, operational excellence; disciplined, selective, and long-term focus in making investments; and Industry-leading returns on capital and superior cash flow. In view of this, a triennial frequency is more consistent with the longterm orientation of our business and compensation strategies as outlined in the "Compensation Discussion and Analysis" section of this proxy. A triennial frequency also gives shareholders a longer period of time to evaluate the effectiveness of key compensation strategies and related business outcomes. Conversely, an annual vote could encourage short-term orientation and contradict the key fundamentals of our approach to managing the business and building long-term, sustainable growth in shareholder value. Consistent with the Board's commitment to excellence in governance and responsiveness to shareholders, the Board will, however, follow the frequency that receives the plurality of votes cast by shareholders on this non-binding resolution. Furthermore, if the plurality of votes cast by shareholders is for triennial frequency, the Board will commit to hold the next frequency vote in three years, rather than the statutory requirement to hold this vote at least every six years. This approach recognizes that the frequency vote is a new requirement and shareholders need an opportunity to evaluate and assess the stability and the effectiveness of the compensation program before committing to a six-year period between management-sponsored frequency votes. In this way, shareholders will be assured the opportunity to re-evaluate the frequency issue in coordination with the next advisory vote to approve executive compensation. For the reasons discussed above, the Board recommends that future advisory votes on executive compensation be held every three years." (Exxon Mobil, Proxy Statement, April 13, 2011)

"Our Board of Directors has determined that holding a "say-on-pay" vote every three years is most appropriate for Ciena and recommends that you vote to hold such advisory vote in the future every third year, for the following reasons. First,...holding an advisory vote every three years offers the closest alignment with Ciena's approach to executive compensation...Specifically, our executive compensation programs are designed to enhance the long-term growth of Ciena and reward performance over a multi-year period. For example, the stock awards granted to our executive team generally have four-year vesting periods, and the performance stock awards granted to our executives in fiscal 2011 included a performance period over multiple fiscal years. The Board believes that there is some risk that an annual advisory vote on executive compensation could lead to a short-term stockholder perspective regarding executive compensation that does not align well with the longer-term approach used by our Compensation Committee. We believe a three-year cycle for the stockholder advisory vote will provide investors the most meaningful timing alternative by which to evaluate the effectiveness of our executive compensation strategies and their alignment with Ciena's performance, financial results and business. Second, the Board believes that a triennial "say on pay" vote would not foreclose stockholder engagement on executive compensation during interim periods. Specifically, Ciena provides stockholders with other meaningful means by which to share their views about our executive compensation practices. Stockholders can currently provide input to the Board by communicating directly with the Board, its committees or individual directors as indicated in "Corporate Governance and the Board of Directors - Communicating with the Board of Directors" above. Thus, we view the advisory vote on executive compensation as an additional, but not exclusive, opportunity for our stockholders to communicate their views on Ciena's executive compensation programs. The Board weighed these reasons against the arguments in support of conducting the advisory vote annually. In particular, the Board considered the value of the opportunity for stockholder input at each annual meeting, as well as the belief that annual votes would promote greater accountability on executive compensation. Although the Board believes that these and other positions put forth in favor of an annual "say on pay" vote are not without merit, on balance, the Board believes that a triennial approach 
is most appropriate for Ciena and recommends that voting alternative to stockholders. The Governance and Nominations Committee of the Board of Directors intends to periodically reassess that view and, if it determines appropriate, may provide for an advisory vote on executive compensation on a more frequent basis." (Ciena, Proxy Statement, February 2, 2011)

\section{Examples of management recommendations in favor of biennial SOP votes}

"In 2010, when we gave our shareholders the opportunity to vote on our executive compensation policies and procedures, we indicated that the Board planned to submit an advisory vote every two years to foster a more long-term approach to evaluating our executive compensation program. At the same time, the Board believes that biennial votes provide assurance that the Board and the Compensation Committee remain accountable for executive compensation decisions on a frequent basis. Further, we maintain robust investor outreach activities through which we obtain ongoing feedback concerning our executive compensation program and how we disclose that program. In 2010, as has been the case for many years, we not only listened to our investors' views; we actively sought out those views and welcomed and implemented a number of their suggestions. Accordingly, your Board believes that a biennial advisory vote is preferable, as it would foster a more long-term approach to evaluating our executive compensation program while maintaining accountability for executive compensation decisions. If a plurality of the votes cast on this matter at the Annual Meeting is cast in favor of biennial advisory votes on executive compensation, the Company would adopt this approach. Moreover, as a further commitment to our shareholders and to encourage their input, and even though the Company is legally required to hold advisory votes on the frequency of future advisory votes on executive compensation only once every six calendar years, the Board has determined that, should a plurality of the votes cast at the Annual Meeting express a preference for biennial advisory votes, the Company would hold frequency votes biennially as well. On this basis, the next advisory vote on executive compensation, as well as the next frequency vote, would take place at the Company's 2013 Annual Meeting. Although the frequency vote is non-binding, the Compensation Committee and the Board will review the results of the vote. Consistent with Pfizer's record of shareholder responsiveness, they will consider shareholders' views and take them into account in determining the frequency of future advisory votes on executive compensation." (Pfizer, Proxy Statement, March 22, 2011)

\section{Examples of management recommendations in favor of annual SOP votes}

"Our Board believes that say-on-pay votes should be conducted every year so that our stockholders may provide us with their direct input on our compensation philosophy, policies and practices, as disclosed in our proxy statement each year. Our Board's determination was based upon the premise that NEO compensation is evaluated, adjusted and approved on an annual basis by our Executive Compensation Committee and that the metrics that are used in determining performance-based award achievements are annual metrics." (Adobe Systems, Proxy Statement, March 10, 2011)

"The Board recommends that the advisory vote to approve named executive officer compensation be held each year as part of our annual stockholders meetings. The Board believes an annual advisory vote can provide relatively timely feedback on our executive compensation arrangements, plans, programs and policies." (KB Home, Proxy Statement, February 25, 2011)

"For each of the past two years, we have provided our stockholders with the right to cast an advisory vote on our executive compensation program and policies for our Named Executives. Therefore, the Board has determined that an advisory vote on executive compensation that occurs every year is the most appropriate alternative for our company going forward. Accordingly, the Board recommends that you 
vote for an annual advisory vote on executive compensation." (Par Pharmaceutical, Proxy Statement, March 30, 2011)

\section{Examples of management "no" recommendations}

"The Board of Directors has determined not to make a recommendation on this proposal, but to wait and consider the views of our stockholders before making any determination as to the appropriate frequency of the stockholder advisory vote on executive compensation." (Advanced Micro Devices, Proxy Statement, March 10, 2011)

"Intel has voluntarily conducted annual "say on pay" votes in each of the last two years, but we welcome the opportunity to submit the three alternative frequencies to our stockholders for consideration. Some commentators have said that a two-year or three-year frequency might be better aligned with compensation trends or programs and would place less emphasis on the results or actions of a single year; other commentators have stated that an annual vote provides a company with more opportunity for timely feedback. We are prepared to operate under any of the three alternative frequencies and look forward to the stockholder vote for input. Because of this rare circumstance in which federal law is requiring that three alternatives be offered to stockholders for consideration, the Board is not making a recommendation as to a favored alternative." (Intel, Proxy Statement, April 4, 2011)

"A majority of the shares of common stock represented at the annual meeting and entitled to vote at the annual meeting is required for advisory approval of this proposal. If none of the alternatives receives a majority vote, the frequency receiving the highest number of votes will be the frequency selected by stockholders. Although the Dodd-Frank Act requires that this vote only be advisory, the Board will present future Say on Pay votes with the frequency selected by stockholders, until another such vote on frequency by the stockholders occurs. The Board does not have a recommendation on the frequency of advisory votes on the compensation of Occidental's named executive officers." (Occidental Petroleum, Proxy Statement, March 24, 2011)

"The following information is provided for your consideration when evaluating the appropriate frequency for an advisory vote:

- UTC's executive compensation programs are heavily weighted toward long-term performance and related incentive opportunities, with the potential for actual payment occurring over a multi-year time span.

- The design of UTC's executive compensation program changes infrequently, to retain alignment of compensation with long-term performance objectives...UTC's current compensation programs are consistent with the longer-term view that the Compensation Committee takes with respect to the most important components of named executive officers' compensation.

- A longer period between votes would provide greater opportunity for shareowners and advisory services to evaluate the operation of UTC's executive compensation programs, and would facilitate more meaningful dialogue with shareowners...

- UTC's practice has been to request that shareowners approve additional shares for future awards under the Company's long-term incentive program on a triennial basis. In each case, these triennial votes have been accompanied by extensive dialogue between UTC and investors concerning UTC's executive compensation practices.

- The Board believes that UTC's executive compensation programs have proven effective in generating enhanced shareowner value. 
The Board thanks shareowners for considering the above information when voting on the appropriate frequency for an advisory vote. The Board of Directors is not making a recommendation on how shareowners should vote on the following resolution because it has decided to first consider the views of UTC's shareowners..."(United Technologies Corporation, Proxy Statement, February 25, 2011) 
Appendix 2 Frequency of SOP votes: proxy advisors' and institutional investors' positions

\section{Institutional Investors}

"As investors with a deep concern about executive pay, we are appealing to Boards of Directors to recommend an annual advisory vote on executive compensation and to investors to vote for the annual vote choice...for a number of reasons.

- Shareholders expect and are accustomed to annual accountability: Executive compensation is too important of an issue for only biennial or triennial consideration. Corporate governance best practice already supports an annual ratification of company auditors and the annual election of directors. Since the board compensation committee makes its decisions yearly regarding salary, discretionary bonuses, severance, etc., an annual shareholder vote is central to proper shareholder oversight. Also a routine positive vote on pay each year affirms to the board that it has presented a clear and convincing case to investors. As investors we also believe shareholders would not find an annual compensation vote burdensome. Shareholders already vote each year on a number of issues, including election of directors and ratification of auditors. There have also been Say on Pay votes for several years, including hundreds of banks receiving TARP funds, and most investors have already set up a system whereby companies deserving extra attention on compensation matters are prioritized for review and action. Investors also currently vote for the Board members on the Compensation Committee, discerning whether a No vote should be cast because of compensation concerns in a routine annual exercise...

- An annual advisory vote is widespread standard practice in countries that require such votes: Shareholders in Australia, France, The Netherlands, Norway, Spain, Sweden and the United Kingdom all vote annually on compensation matters. No other major developed country that provides for advisory votes on pay employs a biennial or triennial standard.

- A biennial or triennial vote would result in less accountability and transparency: ...The Compensation Committee makes some decisions every year, such as setting performance targets or awarding compensation that is not tied directly to performance (such as salaries, employment agreement approvals, discretionary bonuses, "golden hello's" and severance). There should be an opportunity to vote whenever the Compensation Committee has acted.

- A biennial or triennial vote might result in more adversarial shareholder action: If an advisory vote occurs only every two or three years, disenchanted shareholders would be unable to express their concerns annually regarding company pay practices and may have to rely on tools such as letter writing, the filing of shareholder resolutions and voting against compensation committee nominees in the off years.

(Public statement by 39 institutional investors, including CalPERS, the New York State Common Retirement Fund, NYCERS, Hermes UK, Calvert Asset Management, Amalgamated Bank, Walden Asset Management, AFL-CIO, AFSCME, released on January 31, 2011)

"We will generally support a vote once every three years, in keeping with our belief that a properly constituted board, not the shareholder, is best able to address compensation matters in the normal course of fulfilling its responsibilities... Our concern with an annual advisory vote on compensation is that it may compel boards to adjust compensation programs every year to demonstrate that they are effectively managing the compensation process. We believe this approach could lead to a focus on short-term objectives rather than on more stable, long-term objectives, or lead to inconsistencies in the compensation program without a clear long-term focus. In our view, an advisory vote on compensation every three years would remove these biases and better facilitate the development of a compensation program focused on promoting the long-term success of the organization. Let us be clear that we will still hold boards 
accountable for the compensation decisions made. We will continue to monitor annual compensation decisions of our investments, examining whether the board alters the compensation program, uses discretion inappropriately or makes other compensation decisions that in our view are not consistent with a pay-for-performance regime or the creation of long-term shareholder value. In situations where these and other concerns arise, we will consider withholding our support for the election of the compensation committee chair or, in more serious situations, the entire compensation committee of the board. "(Press release by the Ontario Teachers' Pension Plan, February 3, 2011)

"BlackRock will generally opt for a triennial vote on Say on Pay. We believe that shareholders should undertake an annual review of executive compensation and express their concerns through their vote on the members of the compensation committee. As a result, it is generally not necessary to hold a Say on Pay vote on an annual basis, as the Say on Pay vote merely supplements the shareholder's vote on Compensation Committee members. However, we may support annual Say on Pay votes in some situations, for example, where we conclude that a company has failed to align pay with performance." (Proxy Voting Guidelines for US Securities, March 2011, BlackRock)

\section{Proxy Advisors}

\section{Institutional Shareholder Services (ISS)}

"In line with overall client feedback, ISS is adopting a policy to recommend a vote FOR annual advisory votes on compensation. The MSOP is at its essence a communication vehicle, and communication is most useful when it is received in a consistent and timely manner. ISS supports an annual MSOP vote for many of the same reasons it supports annual director elections rather than a classified board structure: because this provides the highest level of accountability and direct communication by enabling the MSOP vote to correspond to the majority of the information presented in the accompanying proxy statement for the applicable shareholders' meeting. Having MSOP votes every two or three years, covering all actions occurring between the votes, would make it difficult to create the meaningful and coherent communication that the votes are intended to provide. Under triennial elections, for example, a company would not know whether the shareholder vote references the compensation year being discussed or a previous year, making it more difficult to understand the implications of the vote." (ISS, U.S. Corporate Governance Policy 2011 Updates, November 19, 2010)

\section{Glass Lewis \& Co.}

"We believe companies should submit say-on-pay votes to shareholders every year. We believe that the time and financial burdens to a company with regard to an annual vote are relatively small and incremental and are outweighed by the benefits to shareholders through more frequent accountability. Implementing biannual or triennial votes on executive compensation limits shareholders' ability to hold the board accountable for its compensation practices through means other than voting against the compensation committee. Unless a company provides a compelling rationale or unique circumstances for say-on-pay votes less frequent than annually, we will generally recommend that shareholders support annual votes on compensation." (Glass Lewis \& Co., Proxy Paper Guidelines 2011 Proxy Season) ${ }^{36}$

\footnotetext{
${ }^{36}$ In our sample, with the exception of Berkshire Hathaway and Amazon, Glass Lewis always recommended an annual SOP vote.
} 
Appendix 3 Firms' response to high votes against Say on Pay in 2011: excerpts from the 2012 proxy filings for ...

\section{...firms adopting annual frequency of SOP Votes}

Umpqua Holdings Corp., Proxy Statement, April 17, 2012, Dissent in 2011: 61.8\%.

"Our Response to Say on Pay Vote:

A majority of the stockholders who voted on our 2011 "Say on Pay" proposal voted against the proposal. In response to that vote, our board of directors, the Committee and our executive team took immediate and thorough action:

a. The Committee engaged Towers Watson, a leading human resources consulting firm, to perform a review of our executive compensation program and make recommendations for enhancements.

b. Our executive team agreed to amend the equity grants issued in January 2011 to include a vesting condition that limits vesting to the extent that Umpqua's total shareholder return (TSR) does not exceed the KRX total return index, a regional bank index.

c. We met with representatives of Institutional Shareholder Services (ISS) and Glass Lewis to fully understand their view of the "pay for performance" aspect of our compensation program.

d. We engaged Phoenix Advisory Partners to advise on outreach to our institutional shareholders who voted against our say on pay resolution.

e. We met with many of our large institutional shareholders who voted against our 2011 say on pay resolution to advise them of our response and to understand their concerns with our program.

f. We strengthened our stock ownership policy to require that named executive officers acquire and maintain positions in company stock with a value ranging from $150 \%$ to $400 \%$ of base salary.

g. We enhanced our policy to require that at least $50 \%$ of all equity awards to executive officers will be "performance based". In 2011, $100 \%$ of the equity awards to executives were "performance-based".

h. We revised our "hold to retirement" policy to remove the age 62 exemption. $75 \%$ of all net equity awards must be held to retirement."

Jacobs Engineering Group Inc., Proxy Statement, December 16, 2011, Dissent in 2011:53.7\%

During fiscal 2011, the equity compensation component of the Company's pay programs was reevaluated, taking into account the outcome of the shareholder vote on executive compensation at the 2011 Annual Meeting of Shareholders, consultations with the independent consultant of the HR\&C Committee, and discussions with major institutional shareholders. As a result of these considerations, the long-term equity based incentive program now has the following features:

- Instead of time-based restricted stock grants, which were a significant portion of the 2010 equity compensation program, performance-based market stock unit ("MSU") grants (the structure of the MSU grants is described below under "Compensation Discussion and Analysis-Compensation Elements-2011 Equity Awards"), were awarded to the NEOs;

- the CEO MSU grant includes a second performance condition based upon the Company's total shareholder return compared to its peer group over a three-year performance period; 
- The proportion of long-term incentives delivered in the form of stock options granted to the NEOs was reduced so that MSUs comprise the majority of their equity compensation in both shares and value;

- In fiscal 2011 the Company increased the required CEO Company stock ownership guideline from five times to six times base salary;

- New equity award agreements were modified in fiscal 2011 to provide for accelerated vesting after a change in control only if the executive is terminated without cause or quits for good reason ("double trigger vesting");

- In fiscal 2011 the Company adopted a clawback policy that applies when inaccurate financial statements have affected incentive award payments to executive officers..."

Alexandria Real Estate Equities Inc., Proxy Statement, April 27, 2012, Dissent in 2011: 37.5\%

"At our May 2011 annual meeting, we held a non-binding stockholder advisory vote to approve the Company's executive compensation. Over $62 \%$ of votes cast were voted for the proposal and approximately $37 \%$ of votes cast were voted against the proposal...the Committee began a comprehensive study of potential changes to our compensation program to take into account constructive input received from stockholders and to help to ensure that the Company's compensation program continues to reflect good corporate governance and new and emerging best practices.... The principal change is the new employment agreement between the Company and Mr. Marcus. The principal differences between the new agreement and Mr. Marcus's previous employment agreement are summarized below. ...

\begin{tabular}{|l|l|}
\hline \multicolumn{1}{|c|}{ Principal Changes to the Employment Agreement of Mr. Marcus } \\
\hline $\begin{array}{l}\text { Annual incentive bonus based on subjective evaluation by the } \\
\text { Committee. }\end{array}$ & $\begin{array}{l}\text { Formulaic annual incentive bonus program for } 2012 \text { based on } \\
\text { achievement of pre-established corporate goals ( } 60 \%) \text { and } \\
\text { individual performance }(40 \%)\end{array}$ \\
\hline Guaranteed bonus equal to $50 \%$ of base salary. & No guaranteed bonus. \\
\hline $\begin{array}{l}\text { Long-term incentives provided solely in the form of time-based } \\
\text { restricted stock, which was awarded based on subjective } \\
\text { performance reviews. }\end{array}$ & $\begin{array}{l}\text { Two-pronged long-term incentive program for } 2012 \text { that will } \\
\text { include performance-based restricted stock, which can be earned } \\
\text { based on relative and absolute TSR (50\%) and time-based } \\
\text { restricted stock (50\%), which will vest over three years and is } \\
\text { awarded based on a subjective performance review. }\end{array}$ \\
\hline $\begin{array}{l}\text { Initial term of employment was for six years, with automatic } \\
\text { annual renewals thereafter. }\end{array}$ & $\begin{array}{l}\text { Term of employment is for three years, with no automatic } \\
\text { renewals. }\end{array}$ \\
\hline $\begin{array}{l}\text { Section } 280 \mathrm{G} \text { excise tax gross-up upon qualifying termination of } \\
\text { employment in connection with a Change of Control. }\end{array}$ & Eliminated. \\
\hline $\begin{array}{l}\text { Tax gross-up reimbursement of up to } \$ 1 \text { million per year upon } \\
\text { the vesting of shares of restricted stock as received. }\end{array}$ & Eliminated. \\
\hline $\begin{array}{l}\text { Basis for change in control or termination payment was annual } \\
\text { salary plus most recent bonus. }\end{array}$ & $\begin{array}{l}\text { Basis for change in control or termination payment is annual } \\
\text { salary plus average bonus over previous three years. }\end{array}$ \\
\hline
\end{tabular}

(source: Alexandria Real Estate Equities Inc., Proxy Statement, April 27, 2012, p. 26)

Monsanto Co., Proxy Statement, December 9, 2011, Dissent in 2011: 33.8\%

At our January 2011 annual meeting, our shareowners voted to approve our fiscal 2010 executive compensation program, but approximately one-third of the votes cast did not support the measure. The Committee was pleased that a significant majority of our largest shareowners supported the proposal ...We also focused on seeking feedback from those of our top 50 shareowners that we learned, from their Form N-PX filings or correspondence, did not support our fiscal 2010 executive compensation program...Many of these investors were not available, or were unwilling, to engage in a dialogue about our executive compensation program. From those shareowners 
available to talk with us, we could not identify a common reason for the negative votes or a common suggestion for improvements to our executive compensation program. However, we did appreciate the opportunity to engage in thorough discussions of our executive compensation program, and a number of these investors informed us the dialogue had enabled them to increase their understanding of our program...The Committee has reviewed the investor feedback received in connection with the last annual meeting and...no specific component of the program was altered based on shareowner feedback...

\section{...firms adopting triennial frequency of SOP Votes}

Eagle Bulk Shipping Inc., Proxy Statement, April 23, Dissent in 2011: 42.9\%.

"Shareholders approved the say-on-pay vote relating to our 2010 compensation, and approved the recommendation of the Board of Directors to hold future say-on-pay votes every three years. As a result, the next say-on-pay vote will be held no later than the 2014 Annual Meeting of Shareholders. In light of the approval of the say-on-pay vote, the Compensation Committee did not make specific changes to our executive compensation program in response to the vote..."

Primo Water Corp., Proxy Statement, March 30, 2012, Dissent in 2011: 32.0\%.

"A majority (68\%) of the votes cast on the "say on pay" proposal at that meeting were voted in favor of the proposal... The Compensation Committee believes that these results affirm our stockholders' support of the Company's approach to executive compensation..."

SandRidge Energy Inc., Proxy Statement, April 9, 2012, Dissent in 2011: 29.0\%

"At our 2011 annual meeting, the Company's stockholders approved the compensation provided to our named executive officers in an advisory vote with over $70 \%$ of ballots cast being voted to approve the executive compensation program. The Compensation Committee believes this affirms the stockholders' support of the Company's executive compensation program and, therefore, did not change its overall approach to compensation during 2011."

\section{Covanta Holding Corp., Proxy Statement, March 27, 2012, Dissent in 2011: $38.8 \%$}

"Our stockholders voted in favor of the 2010 compensation of our named executive officers in our Say on Pay advisory vote at our 2011 Annual Meeting of Stockholders. However, due in part to the relatively narrow margin of approval, and concerns raised by both a proxy advisory firm and certain institutional stockholders regarding the linkage between performance and pay, we engaged in discussions with the proxy advisory firm and certain of our institutional stockholders in order to understand the reasons for their negative recommendations... These discussions highlighted the difference in the metrics used by the proxy advisory firm and stockholders to measure performance (total stockholder return compared to a peer group) and how the Growth Equity Awards were required to be reported in our 2010 Summary Compensation Table... Recognizing the importance of our stockholders' concerns and the need to address them in a manner consistent with the goals of our executive compensation program, we reviewed our compensation approach...Accordingly, in March 2012 the Compensation Committee approved, for future grants, a new program of performance-based equity awards for named executive officers that will only vest upon satisfaction of TSR-based performance as measured against a peer group comprised as follows: (1) $50 \%$ Standard \& Poors 400; (2) 25\% Dow Jones Waste Index; and (3) 25\% Dow Jones Electric Utilities index." 
Figure 1 Say-When-On-Pay (SWOP): frequency of management recommendations in favor of biennial/triennial say on pay votes during the 2011 proxy season

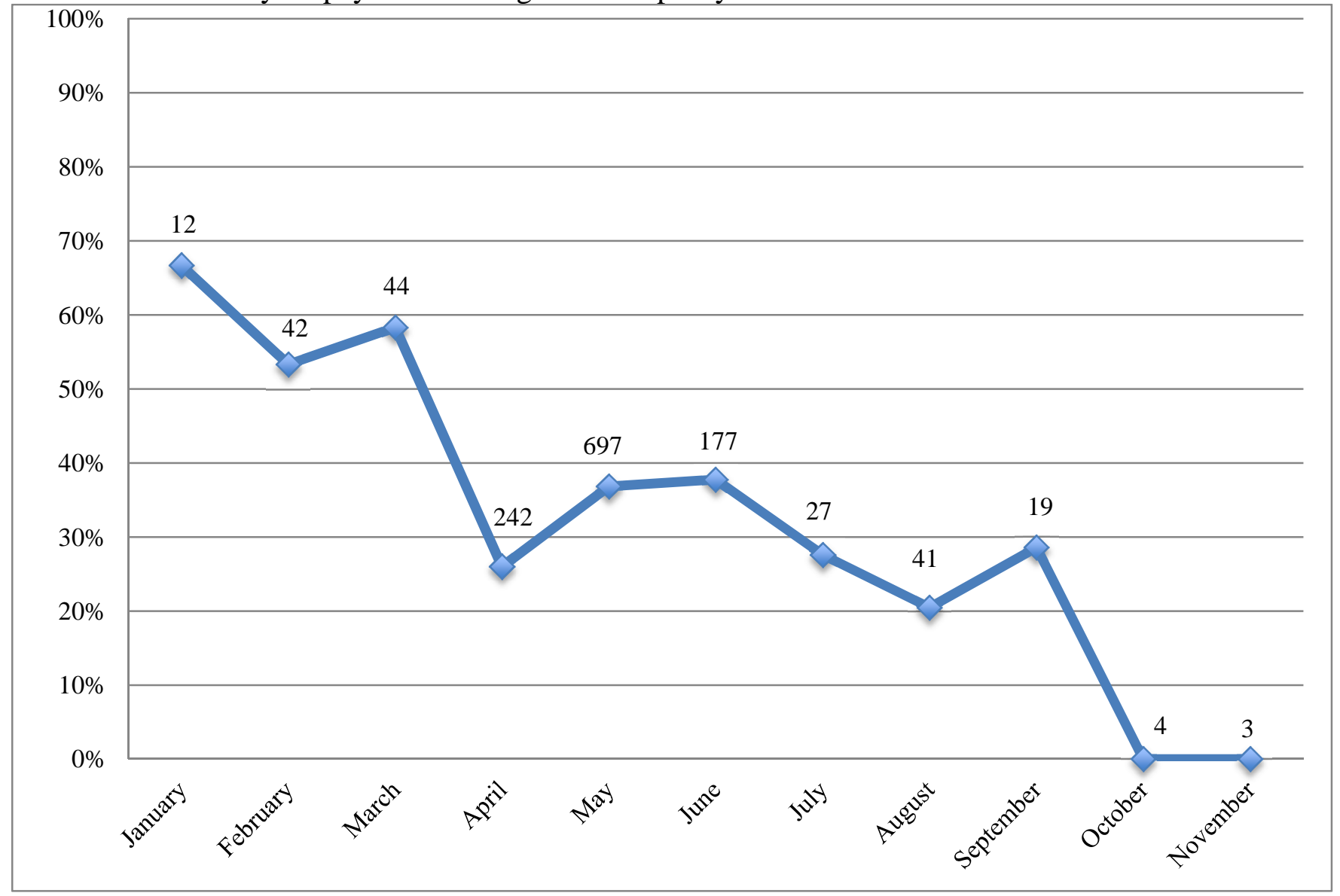

Figure 1 presents the frequency of management say-when-on-pay (SWOP) recommendations in favor of holding biennial or triennial SOP votes by month for the annual meeting dates between January and November 2011. The figure also displays the number of annual meetings held for each month (right above the trend line). 
Table 1 Say-When-On-Pay (SWOP): Frequency of management recommendations and voting outcome

\begin{tabular}{|c|c|c|c|c|c|}
\hline & \multirow[t]{2}{*}{ All } & \multicolumn{3}{|c|}{ By Management Recommendation } & \multirow[b]{2}{*}{ None } \\
\hline & & Annual & Biennial & Triennial & \\
\hline $\mathrm{N}$ & 1,365 & 841 & 32 & 452 & 40 \\
\hline$\%$ & $100.0 \%$ & $61.6 \%$ & $2.3 \%$ & $33.1 \%$ & $2.9 \%$ \\
\hline Mean SWOP Votes for Annual & $75.5 \%$ & $86.6 \%$ & $58.3 \%$ & $56.5 \%$ & $71.5 \%$ \\
\hline Mean SWOP Votes for Biennial & $1.7 \%$ & $0.9 \%$ & $28.6 \%$ & $1.4 \%$ & $2.7 \%$ \\
\hline Mean SWOP Votes for Triennial & $21.3 \%$ & $11.2 \%$ & $11.3 \%$ & $40.8 \%$ & $21.9 \%$ \\
\hline \multicolumn{6}{|l|}{ Number of firms with } \\
\hline Highest voting support for annual & 1,239 & 839 & 28 & 335 & 37 \\
\hline Highest voting support for biennial & 4 & - & 4 & - & - \\
\hline Highest voting support for triennial & 122 & 2 & 0 & 117 & 3 \\
\hline
\end{tabular}

Table 1 presents the distribution of say-when-on-pay (SWOP) votes by management recommendation. SWOP Votes for Annual (Biennial, Triennial) is defined as number of votes cast in favor of annual (biennial, triennial) frequency of say on pay scaled by total number of votes cast (i.e. the sum of votes cast in favor of annual, biennial or triennial votes plus abstention votes) (source: ISS). 
Table 2 Influence of management recommendations

Panel A: Determinants of votes on frequency of say on pay

\begin{tabular}{|c|c|c|c|c|}
\hline & $\begin{array}{l}\text { Model (1) } \\
\text { Coefficient } \\
(t \text {-statistic) }\end{array}$ & $\begin{array}{l}\text { Model (2) } \\
\text { Coefficient } \\
(t \text {-statistic) }\end{array}$ & $\begin{array}{l}\text { Model (3) } \\
\text { Coefficient } \\
(t \text {-statistic) }\end{array}$ & $\begin{array}{l}\text { Model (4) } \\
\text { Coefficient } \\
(t \text {-statistic }) \\
\end{array}$ \\
\hline \multirow[t]{2}{*}{ Intercept } & $0.366^{* * *}$ & $0.201^{* * *}$ & $0.201^{* * *}$ & $0.374^{* * *}$ \\
\hline & $(7.426)$ & $(6.262)$ & $(6.249)$ & $(11.084)$ \\
\hline \multirow[t]{2}{*}{$\%$ Votes Controlled by Insiders } & $0.574^{* * *}$ & $0.404^{* * *}$ & $0.406^{* * *}$ & $0.514^{* * *}$ \\
\hline & $(9.770)$ & $(9.876)$ & $(9.876)$ & $(11.943)$ \\
\hline \multirow[t]{2}{*}{$\%$ Non-Institutional Block Ownership } & $0.343^{* * *}$ & $0.223^{* *}$ & $0.225^{* *}$ & $0.359^{* * *}$ \\
\hline & $(2.738)$ & $(2.505)$ & $(2.503)$ & $(4.078)$ \\
\hline \multirow[t]{2}{*}{$\%$ Inst. Own. in Favor of Annual } & $-0.465^{* * *}$ & $-0.340^{* * *}$ & $-0.336^{* * *}$ & $-0.378^{* * *}$ \\
\hline & $(-6.304)$ & $(-6.494)$ & $(-6.427)$ & $(-6.994)$ \\
\hline \multirow[t]{2}{*}{$\%$ Inst. Own. in Favor of Triennial } & $0.485^{* * *}$ & $0.417^{* * *}$ & $0.427^{* * *}$ & $0.404^{* * *}$ \\
\hline & $(3.145)$ & $(3.992)$ & $(4.059)$ & $(3.830)$ \\
\hline \multirow[t]{2}{*}{$\%$ Inst. Own. With No Stated Preference } & $-0.256^{* * *}$ & $-0.196^{* * *}$ & $-0.195^{* * *}$ & $-0.232^{* * *}$ \\
\hline & $(-6.846)$ & $(-7.964)$ & $(-7.891)$ & $(-9.401)$ \\
\hline \multirow[t]{2}{*}{$\ln (M V$ Equity $)$} & -0.003 & $0.004^{*}$ & $0.004^{*}$ & $-0.006^{* *}$ \\
\hline & $(-0.754)$ & $(1.776)$ & $(1.697)$ & $(-2.453)$ \\
\hline \multirow[t]{2}{*}{ Abnormal Returns } & 0.018 & 0.006 & 0.006 & $0.016^{*}$ \\
\hline & $(1.250)$ & $(0.613)$ & $(0.671)$ & $(1.699)$ \\
\hline \multirow[t]{2}{*}{ Return on Assets } & $0.096^{*}$ & $-0.078^{* *}$ & $-0.078^{* *}$ & $0.096^{* *}$ \\
\hline & $(1.873)$ & $(-2.044)$ & $(-2.049)$ & $(2.541)$ \\
\hline \multirow[t]{2}{*}{ Mgmt SWOP Rec: Triennial } & & $0.259^{* * *}$ & & \\
\hline & & (38.594) & & \\
\hline \multirow[t]{2}{*}{ Mgmt SWOP Rec: Triennial_Early Proxy Season } & & & $0.297^{* * *}$ & \\
\hline & & & $(20.557)$ & \\
\hline \multirow[t]{2}{*}{ Mgmt SWOP Rec: Triennial_Late Proxy Season } & & & $0.253^{* * *}$ & \\
\hline & & & $(36.193)$ & \\
\hline \multirow[t]{2}{*}{ Residual Mgmt SWOP Rec: Triennial } & & & & $0.254^{* * *}$ \\
\hline & & & & $(37.466)$ \\
\hline $\mathrm{N}$ & 1,365 & 1,325 & 1,325 & 1,300 \\
\hline Adjusted $\mathrm{R}^{2}$ & 0.352 & 0.744 & 0.744 & 0.716 \\
\hline
\end{tabular}


Panel B: Determinants of shareholder votes on proposals to declassify the board

\begin{tabular}{|c|c|c|}
\hline & $\begin{array}{c}\text { Model (1) } \\
\text { Coefficient } \\
(t \text {-statistic }) \\
\end{array}$ & $\begin{array}{c}\text { Model (2) } \\
\text { Coefficient } \\
(t \text {-statistic }) \\
\end{array}$ \\
\hline \multirow[t]{2}{*}{ Intercept } & $0.661^{* * *}$ & $0.568^{* * *}$ \\
\hline & $(15.257)$ & $(13.528)$ \\
\hline \multirow[t]{2}{*}{$\%$ Votes Controlled by Insiders } & $-0.426^{* * *}$ & $-0.351^{* * *}$ \\
\hline & $(-2.792)$ & $(-2.652)$ \\
\hline \multirow[t]{2}{*}{$\%$ Non-Institutional Block Ownership } & $-0.472^{* * *}$ & -0.221 \\
\hline & $(-3.352)$ & $(-1.580)$ \\
\hline \multirow[t]{2}{*}{ \% Institutional Ownership } & $0.226^{* * *}$ & $0.207^{* * *}$ \\
\hline & (7.328) & $(5.810)$ \\
\hline \multirow[t]{2}{*}{$\ln (M V$ Equity) } & 0.005 & 0.002 \\
\hline & $(1.208)$ & $(0.629)$ \\
\hline \multirow[t]{2}{*}{ Abnormal Returns } & $0.069^{* *}$ & 0.005 \\
\hline & $(2.460)$ & $(0.356)$ \\
\hline \multirow[t]{2}{*}{ Return on Assets } & -0.078 & -0.038 \\
\hline & $(-0.735)$ & $(-0.498)$ \\
\hline \multirow[t]{2}{*}{ Mgmt Recommends For } & & $0.244^{* * *}$ \\
\hline & & $(26.926)$ \\
\hline $\mathrm{N}$ & 258 & 258 \\
\hline Adjusted $\mathrm{R}^{2}$ & 0.128 & 0.776 \\
\hline
\end{tabular}

Table 2, Panel A, presents the results for the determinants of votes on the frequency of say on pay, or say-when-onpay (SWOP) votes. The dependent variable, SWOP Votes for Triennial, is defined as number of SWOP votes cast in favor of triennial votes scaled by total number of votes cast, i.e. sum of votes cast in favor of annual, biennial or triennial votes plus abstention votes (source: ISS). \% Votes Controlled by Insiders is equal to the fraction of shares owned by non-director executives and directors and corrected for cases with multiple share classes with different voting rights (source: ExecuComp, ISS Directors Dataset and hand collected data). \% Non-Institutional Block Ownership is the percentage of equity owned by institutions not covered by Thomson Reuters' database of 13-F holdings with ownership greater than 5\% (source: hand collected data). \% Institutional Ownership in Favor of Annual (Triennial) is the percentage of equity owned by 13-F institutions that have expressed a preference for annual (triennial) SOP votes (source: Hauder 2011, Thomson Reuters and hand collected data). \% Institutional Ownership With No Stated Preference is the percentage of equity owned by 13-F institutions that have expressed no preference for annual or triennial SOP votes (source: Hauder 2011, Thomson Reuters and hand collected data). $\ln (M V$ Equity) is the natural logarithm of the market value of equity calculated as the number of shares outstanding as of the end of the most recent fiscal year ending before the annual meeting (Compustat data item csho) times price at fiscal year close (Compustat data item prcc_f) (source: Compustat). Abnormal Returns are size-adjusted returns for the most recent fiscal year ending before the annual meeting (source: CRSP). Return on Assets is the firm's return on assets (ROA) for the most recent fiscal year ending before the annual meeting calculated as earnings before extraordinary items (Compustat data item $i b$ ) scaled by average total assets (Compustat item at) (source: Compustat). Mgmt SWOP Rec: Triennial is an indicator variable that is equal to one if the management recommends voting in favor of holding a triennial SOP vote (source: ISS). Mgmt SWOP Rec: Triennial-Early Proxy Season (Mgmt SWOP Rec: Triennial-Late Proxy Season) is an indicator variable that is equal to one if the management recommends voting in favor of holding a triennial SOP vote and does so in the first three months (after the first three months) of the proxy season (source: ISS). Residual Mgmt SWOP Rec: Triennial is the residual from the logistic regression in Table 8, Panel A, Model (1).

Table 2, Panel B, presents the results for the determinants of votes on proposals to declassify the board submitted first by shareholders and then (in the subsequent year) by management (129f firms, 258 proposals, between 2002 and 2011, source: ISS) The dependent variable, \% VotesFor, is defined as number of votes cast in favor of declassifying the board scaled by total number of votes cast (i.e. sum of votes cast in favor, against or abstain; source: ISS). \% Votes Controlled by Insiders is equal to the fraction of shares owned by non-director executives and directors and corrected for cases with multiple share classes with different voting rights (source: ExecuComp, ISS Directors Dataset and hand collected data). \% Non-Institutional Block Ownership is the percentage of equity owned by institutions not covered by Thomson Reuters' database of 13-F holdings with ownership greater than 5\% (source: hand collected data). \% Institutional Ownership is the percentage of equity owned by $13-\mathrm{F}$ institutions (source: Thomson Reuters). $\ln (M V$ Equity) is the natural logarithm of the market value of equity calculated as the number of shares outstanding as of the end of the most recent fiscal year ending before the annual meeting (Compustat data item $c s h o$ ) times price at fiscal year close (Compustat data item prcc_f) (source: Compustat). Abnormal Returns are size-adjusted returns for the most recent fiscal year ending before the annual meeting (source: CRSP). Return on 
Assets is the firm's return on assets (ROA) for the most recent fiscal year ending before the annual meeting calculated as earnings before extraordinary items (Compustat data item ib) scaled by average total assets (Compustat item at) (source: Compustat). Mgmt Recommends For is an indicator variable that is equal to one if the management recommends in favor of declassifying the board (source: ISS).

${ }^{* * * *},{ }^{* *}$, and ${ }^{*}$ denote significance at the $0.01,0.05$, and 0.10 level, respectively, based on a two-tailed test. Reported tstatistics are based on robust standard errors. 
Table 3 Determinants of votes on frequency of say on pay when management recommends triennial

Panel A: The role of management credibility

\begin{tabular}{|c|c|c|c|c|c|c|}
\hline & $\begin{array}{c}\text { Model (1) } \\
\text { Coefficient } \\
(t \text {-statistic })\end{array}$ & $\begin{array}{l}\text { Model (2) } \\
\text { Coefficient } \\
(t \text {-statistic })\end{array}$ & $\begin{array}{c}\text { Model (3) } \\
\text { Coefficient } \\
(t \text {-statistic) }\end{array}$ & $\begin{array}{l}\text { Model (4) } \\
\text { Coefficient } \\
(t \text {-statistic) }\end{array}$ & $\begin{array}{c}\text { Model (5) } \\
\text { Coefficient } \\
(t \text {-statistic })\end{array}$ & $\begin{array}{c}\text { Model (6) } \\
\text { Coefficient } \\
(t \text {-statistic) }\end{array}$ \\
\hline \multirow[t]{2}{*}{ Intercept } & $0.419^{* * * *}$ & $0.421^{* * *}$ & $0.442^{* * * *}$ & $0.421^{* * *}$ & $0.423^{* * *}$ & $0.448^{* * *}$ \\
\hline & $(7.101)$ & $(7.390)$ & $(7.576)$ & (7.304) & $(7.267)$ & $(8.129)$ \\
\hline \multirow[t]{2}{*}{$\%$ Votes Controlled by Insiders } & $0.633^{* * *}$ & $0.622^{* * * *}$ & $0.625^{* * *}$ & $0.606^{* * *}$ & $0.624^{* * *}$ & $0.580^{* * * *}$ \\
\hline & (14.199) & $(14.517)$ & $(14.302)$ & $(14.167)$ & $(14.084)$ & $(14.437)$ \\
\hline \multirow[t]{2}{*}{ \% Non-Institutional Block Ownership } & $0.545^{* * *}$ & $0.548^{* * *}$ & $0.542^{* * *}$ & $0.535^{* * *}$ & $0.545^{* * *}$ & $0.534^{* * *}$ \\
\hline & $(6.250)$ & $(6.494)$ & $(6.176)$ & $(6.115)$ & $(6.379)$ & $(6.402)$ \\
\hline \multirow[t]{2}{*}{ \% Inst. Own. in Favor of Annual } & $-0.623^{* * *}$ & $-0.645^{* * *}$ & $-0.628^{* * *}$ & $-0.643^{* * *}$ & $-0.601^{* * *}$ & $-0.647^{* * *}$ \\
\hline & $(-6.090)$ & $(-6.280)$ & $(-6.229)$ & $(-6.677)$ & $(-5.990)$ & $(-6.912)$ \\
\hline \multirow[t]{2}{*}{$\%$ Inst. Own. in Favor of Triennial } & 0.368 & 0.368 & 0.351 & 0.435 * & 0.328 & $0.380 *$ \\
\hline & $(1.515)$ & $(1.579)$ & $(1.473)$ & $(1.806)$ & $(1.354)$ & $(1.673)$ \\
\hline \multirow[t]{2}{*}{$\%$ Inst. Own. With No Stated Preference } & $-0.166^{* * * *}$ & $-0.156^{* * *}$ & $-0.169^{* * *}$ & $-0.172^{* * *}$ & $-0.163^{* * *}$ & $-0.162^{* * *}$ \\
\hline & $(-3.779)$ & $(-3.613)$ & $(-3.937)$ & $(-4.033)$ & $(-3.744)$ & $(-3.988)$ \\
\hline \multirow[t]{2}{*}{$\ln (M V$ Equity $)$} & $0.007^{*}$ & $0.007^{* *}$ & 0.006 & $0.006^{*}$ & $0.007^{* *}$ & $0.006^{*}$ \\
\hline & $(1.888)$ & $(2.031)$ & $(1.523)$ & $(1.798)$ & $(2.057)$ & $(1.762)$ \\
\hline \multirow[t]{2}{*}{ Abnormal Returns } & 0.022 & 0.015 & 0.023 & 0.022 & 0.020 & 0.015 \\
\hline & $(1.249)$ & $(0.855)$ & $(1.296)$ & $(1.283)$ & (1.159) & $(0.862)$ \\
\hline \multirow[t]{2}{*}{ Return on Assets } & -0.074 & -0.083 & -0.078 & -0.071 & -0.048 & -0.060 \\
\hline & $(-1.296)$ & $(-1.496)$ & $(-1.361)$ & $(-1.316)$ & $(-0.858)$ & $(-1.136)$ \\
\hline \multirow[t]{2}{*}{ High Votes Against SOP } & & $-0.049^{* * *}$ & & & & $-0.046^{* * *}$ \\
\hline & & $(-4.033)$ & & & & $(-3.783)$ \\
\hline \multirow[t]{2}{*}{ High Votes Withheld from Directors } & & & $-0.022^{* *}$ & & & $-0.020^{* *}$ \\
\hline & & & $(-2.330)$ & & & $(-2.131)$ \\
\hline \multirow[t]{2}{*}{ High Votes Against Mgmt Proposals } & & & & $-0.084^{* * *}$ & & $-0.082^{* * *}$ \\
\hline & & & & $(-3.079)$ & & $(-3.140)$ \\
\hline \multirow[t]{2}{*}{ Mgmt Issues Forecast } & & & & & -0.016 & -0.016 \\
\hline & & & & & $(-1.532)$ & $(-1.584)$ \\
\hline \multirow[t]{2}{*}{ Mgmt Forecast Error } & & & & & $-1.238^{* *}$ & $-1.004^{*}$ \\
\hline & & & & & $(-2.288)$ & $(-1.833)$ \\
\hline $\mathrm{N}$ & 484 & 484 & 484 & 484 & 484 & 484 \\
\hline Adjusted $\mathrm{R}^{2}$ & 0.699 & 0.707 & 0.702 & 0.706 & 0.704 & 0.721 \\
\hline
\end{tabular}


Panel B: The role of CEO pay duration

\begin{tabular}{|c|c|c|c|c|}
\hline & $\begin{array}{c}\text { Model (1) } \\
\text { Coefficient } \\
(t \text {-statistic }) \\
\end{array}$ & $\begin{array}{c}\text { Model (2) } \\
\text { Coefficient } \\
(t \text {-statistic }) \\
\end{array}$ & $\begin{array}{l}\text { Model (3) } \\
\text { Coefficient } \\
(t \text {-statistic }) \\
\end{array}$ & $\begin{array}{l}\text { Model (4) } \\
\text { Coefficient } \\
(t \text {-statistic) } \\
\end{array}$ \\
\hline \multirow[t]{2}{*}{ CEO Pay Duration } & -0.022 & & & -0.020 \\
\hline & $(-0.944)$ & & & $(-0.854)$ \\
\hline \multirow[t]{2}{*}{ Book-to-Market Ratio } & & -0.028 & & -0.033 \\
\hline & & $(-1.149)$ & & $(-1.310)$ \\
\hline \multirow[t]{2}{*}{$R \& D /$ Total Assets } & & -0.094 & & -0.074 \\
\hline & & $(-0.957)$ & & $(-0.742)$ \\
\hline \multirow[t]{2}{*}{ Volatility } & & 0.852 & & 0.911 \\
\hline & & $(1.032)$ & & $(1.093)$ \\
\hline \multirow[t]{2}{*}{ CEO Equity Pay Ratio } & & & $-0.035^{*}$ & $-0.036^{*}$ \\
\hline & & & $(-1.889)$ & $(-1.838)$ \\
\hline Controls & Included & Included & Included & Included \\
\hline $\mathrm{N}$ & 484 & 484 & 481 & 481 \\
\hline Adjusted $\mathrm{R}^{2}$ & 0.724 & 0.723 & 0.722 & 0.726 \\
\hline
\end{tabular}

Table 3 presents the results for the determinants of SWOP votes for the sub-sample of companies recommending triennial SOP votes. The dependent variable, SWOP Votes for Triennial, is defined as number of SWOP votes cast in favor of triennial votes scaled by total number of votes cast, i.e. sum of votes cast in favor of annual, biennial or triennial votes plus abstention votes (source: ISS).

Panel A reports the results for a benchmark model and additional management credibility variables. Control variables and management credibility variables are defined as follows.

$\%$ Votes Controlled by Insiders is equal to the fraction of shares owned by non-director executives and directors and corrected for cases with multiple share classes with different voting rights (source: ExecuComp, ISS Directors Dataset and hand collected data). \% Non-Institutional Block Ownership is the percentage of equity owned by institutions not covered by Thomson Reuters' database of 13-F holdings with ownership greater than 5\% (source: hand collected data). \% Institutional Ownership in Favor of Annual (Triennial) is the percentage of equity owned by 13-F institutions that have expressed a preference for annual (triennial) SOP votes (source: Hauder 2011, Thomson Reuters and hand collected data). \% Institutional Ownership With No Stated Preference is the percentage of equity owned by $13-\mathrm{F}$ institutions that have expressed no preference for annual or triennial SOP votes (source: Hauder 2011, Thomson Reuters and hand collected data). $\ln (M V$ Equity) is the natural logarithm of the market value of equity calculated as the number of shares outstanding as of the end of the most recent fiscal year ending before the annual meeting (Compustat data item $c s h o$ ) times price at fiscal year close (Compustat data item prcc_f) (source: Compustat). Abnormal Returns are size-adjusted returns for the most recent fiscal year ending before the annual meeting (source: CRSP). Return on Assets is the firm's return on assets (ROA) for the most recent fiscal year ending before the annual meeting calculated as earnings before extraordinary items (Compustat data item $i b$ ) scaled by average total assets (Compustat item at) (source: Compustat). High Votes Against SOP is an indicator variable that is equal to one if SOP Voting Dissent at the concurrent meeting is greater than 20\% (source: ISS). High Votes Withheld from Directors is an indicator equal to one if the maximum votes withheld from directors over the 2008-2010 annual meetings exceed 20\% (source: ISS). High Votes Against Mgmt Proposals is an indicator equal to one if the maximum votes cast against management proposals over the 2008-2010 period is more than 20\% (source: ISS). Mgmt Issues Forecast is an indicator variable that is equal to one if the firm issues at least one management forecast in 2010 and zero otherwise (source: First Call Company Issued Guidelines Database). Mgmt Forecast Error is the average absolute annual management forecast error over 2010. The forecast error is calculated as actual less forecast scaled by price at the end of the month preceding the estimate date. (source: First Call Company Issued Guidelines Database)

Panel B reports the results for additional duration variables. All variables included in model (6) of Panel A are included but suppressed for ease of exposition. Additional variables include: CEO Pay Duration is the measure of CEO pay duration reported in Table 3 of Gopalan et al. (2012). Book-to-Market Ratio is the book value of equity (Compustat data item ceq) scaled by market value of equity (calculated as the number of shares outstanding as of the end of the most recent fiscal year ending before the annual meeting (Compustat data item $c s h o$ ) times price at fiscal year close (Compustat data item prcc_f)) (source: Compustat). $R \& D /$ Total Assets is R\&D expenses (Compustat data item $x r d$ ) divided by total assets (Compustat data item at), with missing R\&D expenses set equal to 0. (source: Compustat). Volatility is the standard deviation of daily returns over the 12 month window prior to the annual meeting date (source: CRSP). CEO Equity Pay Ratio is equal to CEO Equity Pay divided by CEO Equity Pay plus CEO Cash Pay, where CEO Cash Pay is the sum of salary, bonus and other cash pay and CEO Equity Pay is the value of equity grants (restricted stock and stock options) (source: ExecuComp). ${ }^{* * *},{ }^{* *}$, and ${ }^{*}$ denote significance at the 0.01 , 0.05 , and 0.10 level, respectively, based on a two-tailed test. Reported t-statistics are based on robust standard errors. 
Table 4 Implementation of frequency of SOP votes

Implementation for all companies $(\mathrm{N}=1,346)$

Winning Frequency (most votes)

\begin{tabular}{cccccc} 
& & Annual & Biennial & Triennial & Total \\
Adoption & Annual & 1,221 & 0 & 10 & 1,231 \\
Choice & Biennial & 0 & 4 & 0 & 4 \\
& Triennial & 2 & 0 & 109 & 111 \\
& & & & & \\
& Total & 1,223 & 4 & 119 & 1,346 \\
\hline
\end{tabular}

Table 4 provides information on the implementation of the frequency of SOP votes for S\&P1500 companies that made a frequency recommendation in 2011 and for which implementation data could be collected (source: hand collected data). 
Table 5 Compensation changes following a negative ISS recommendation in 2011: the effect of SOP frequency adoption

\begin{tabular}{|c|c|c|c|c|c|}
\hline & Total & $\begin{array}{c}\text { Triennial } \\
\text { Adopters }\end{array}$ & $\begin{array}{c}\text { Annual } \\
\text { Adopters }\end{array}$ & $\begin{array}{c}\text { Annual } \\
\text { Adopters with } \\
\text { Dissent }<43 \%\end{array}$ & $\begin{array}{c}\text { Annual } \\
\text { Adopters with } \\
\text { Dissent }<30 \%\end{array}$ \\
\hline$N$ & 273 & 70 & 203 & 150 & 72 \\
\hline \% SOP Voting Dissent 2011 & $29.8 \%$ & $16.0 \%$ & $34.5 \%$ & $28.5 \%$ & $20.3 \%$ \\
\hline Compensation Changes 2012 (\% firms) & $53.8 \%$ & $14.3 \%$ & $67.5 \%$ & $58.7 \%$ & $31.9 \%$ \\
\hline ... \% SOP Voting Dissent 2011 & $38.4 \%$ & $22.4 \%$ & $39.6 \%$ & $32.5 \%$ & $21.7 \%$ \\
\hline ... \% SOP Voting Dissent 2012 & $19.6 \%$ & NA & $19.6 \%$ & $18.6 \%$ & $12.1 \%$ \\
\hline
\end{tabular}

Table 5 provides information on companies that received an Against recommendation by ISS for their compensation plan in 2011. $N$ denotes the sample size. \% SOP Voting Dissent 2011 (2012) is defined as the number of votes cast against SOP scaled by the total number of votes cast, i.e. the sum of votes for, votes against and votes abstained at the 2011 (2012) annual meeting (source: ISS). Compensation Changes 2012 (\% firms) is the percentage of companies disclosing compensation changes in the 2012 proxy statement (source: hand collected data).

The first column includes all companies. The second (third) column includes the sub-sample of companies that adopted triennial (annual) SOP frequency. The fourth column includes the sub-sample of companies that adopted annual SOP frequency and had \% SOP Voting Dissent 2011 smaller than the maximum \% SOP Voting Dissent 2011 of companies adopting triennial SOP votes (43\%). The fifth column includes the sub-sample of companies that adopted annual SOP frequency and had \% SOP Voting Dissent 2011 smaller than $30 \%$. 
Table 6 Compensation changes following a negative ISS recommendation in 2011 Multivariate Analysis

\begin{tabular}{|c|c|c|c|}
\hline & $\begin{array}{c}\text { Model (1) } \\
\text { Coefficient } \\
\text { (z-statistic) }\end{array}$ & $\begin{array}{c}\text { Model (2) } \\
\text { Coefficient } \\
\text { (z-statistic) }\end{array}$ & $\begin{array}{c}\text { Model (3) } \\
\text { Coefficient } \\
\text { (z-statistic) }\end{array}$ \\
\hline \multirow[t]{2}{*}{ Intercept } & $0.731^{* * *}$ & $-2.707^{* * *}$ & $-5.650^{* * *}$ \\
\hline & $(4.841)$ & $(-5.283)$ & $(-4.570)$ \\
\hline \multirow[t]{2}{*}{ Triennial Adopter } & $-2.506^{* * *}$ & $-1.244^{* * *}$ & $-0.960^{* *}$ \\
\hline & $(-6.703)$ & $(-2.889)$ & $(-1.969)$ \\
\hline \multirow[t]{2}{*}{ \% SOP Voting Dissent 2011} & & $10.787^{* * *}$ & $10.342^{* * *}$ \\
\hline & & $(6.763)$ & $(5.701)$ \\
\hline \multirow[t]{2}{*}{$\%$ Votes Controlled by Insiders } & & & 0.662 \\
\hline & & & $(0.586)$ \\
\hline \multirow[t]{2}{*}{$\%$ Institutional Ownership } & & & $2.586^{* * *}$ \\
\hline & & & $(2.684)$ \\
\hline \multirow[t]{2}{*}{$\ln (M V$ Equity $)$} & & & 0.139 \\
\hline & & & $(1.303)$ \\
\hline \multirow[t]{2}{*}{ Abnormal Returns } & & & $-0.942^{*}$ \\
\hline & & & $(-1.674)$ \\
\hline \multirow[t]{2}{*}{ Return on Assets } & & & 1.418 \\
\hline & & & $(1.227)$ \\
\hline $\mathrm{N}$ & 269 & 269 & 269 \\
\hline Pseudo $\mathrm{R}^{2}$ & 0.167 & 0.349 & 0.387 \\
\hline
\end{tabular}

Table 6 presents the results for the determinants of compensation changes made by companies in response to the 2011 say on pay vote. The dependent variable, Compensation Changes 2012 is an indicator variable equal to one if a company discloses compensation changes in the 2012 proxy statement (source: hand collected data). Triennial Adopter is an indicator variable equal to one if a company adopted a triennial SOP frequency. \% SOP Voting Dissent 2011 is defined as the number of votes cast against the SOP proposal scaled by the total number of votes cast, i.e. the sum of votes for, votes against and votes abstained at the 2011 annual meeting (source: ISS). \% Votes Controlled by Insiders is equal to the fraction of shares owned by non-director executives and directors and corrected for cases with multiple share classes with different voting rights (source: ExecuComp, ISS Directors Dataset and hand collected data). \% Institutional Ownership is the percentage of equity owned by 13-F institutions (source: Thomson Reuters). $\ln (M V$ Equity) is the natural logarithm of the market value of equity calculated as the number of shares outstanding as of the end of the most recent fiscal year ending before the annual meeting (Compustat data item $c s h o$ ) times price at fiscal year close (Compustat data item $p r c c \_f$ ) (source: Compustat). Abnormal Returns are size-adjusted returns for the most recent fiscal year ending before the annual meeting (source: CRSP). Return on Assets is the firm's return on assets (ROA) for the most recent fiscal year ending before the annual meeting calculated as earnings before extraordinary items (Compustat data item $i b$ ) scaled by average total assets (Compustat item $a t$ ) (source: Compustat). ${ }^{* * *},{ }^{* *}$, and ${ }^{*}$ denote significance at the $0.01,0.05$, and 0.10 level, respectively, based on a two-tailed test. Reported $z$-statistics are based on robust standard errors. 
Table 7 Determinants of management recommendations on frequency of say on pay: Univariate analysis

Panel A: Financial and ownership variables

\begin{tabular}{|c|c|c|c|c|c|c|c|c|c|c|c|}
\hline \multirow{3}{*}{ Variable } & \multicolumn{3}{|c|}{$\begin{array}{c}\text { Full Sample } \\
\mathrm{N}=1,308\end{array}$} & \multicolumn{2}{|c|}{$\begin{array}{c}\text { Triennial Recom. } \\
\qquad \mathrm{N}=474\end{array}$} & \multicolumn{2}{|c|}{$\begin{array}{c}\text { Annual Recom. } \\
\qquad \mathrm{N}=834\end{array}$} & \multicolumn{4}{|c|}{ Triennial vs. annual recom. } \\
\hline & \multirow[t]{2}{*}{ Mean } & \multirow[t]{2}{*}{ Std. Dev. } & \multirow[t]{2}{*}{ Median } & \multirow[t]{2}{*}{ Mean } & \multirow[t]{2}{*}{ Median } & \multirow[t]{2}{*}{ Mean } & \multirow[t]{2}{*}{ Median } & \multicolumn{2}{|c|}{ Mean (t-test) } & \multicolumn{2}{|c|}{ Median (Wilcoxon) } \\
\hline & & & & & & & & Difference & t-statistic & Difference & Z-statistic \\
\hline$\%$ Insider Ownership & 0.070 & 0.113 & 0.030 & 0.093 & 0.042 & 0.057 & 0.023 & 0.036 & 5.58 & 0.019 & 8.11 \\
\hline$\%$ Votes Controlled by Insiders & 0.079 & 0.136 & 0.030 & 0.117 & 0.044 & 0.057 & 0.023 & 0.060 & $7.88^{* * *}$ & 0.021 & $9.00^{* * *}$ \\
\hline$\%$ Non-Institutional Block Ownership & 0.017 & 0.057 & 0.000 & 0.021 & 0.000 & 0.014 & 0.000 & 0.007 & $2.27^{* *}$ & 0.000 & $2.12^{* *}$ \\
\hline \% Institutional Ownership & 0.791 & 0.170 & 0.825 & 0.759 & 0.799 & 0.809 & 0.838 & -0.050 & $-5.20^{* * *}$ & -0.039 & $-4.13^{* * *}$ \\
\hline Overconfident CEO & 0.343 & 0.475 & 0.000 & 0.386 & 0.000 & 0.318 & 0.000 & 0.068 & $2.51^{* *}$ & 0.000 & $2.50^{* *}$ \\
\hline Post March 2011 & 0.925 & 0.263 & 1.000 & 0.878 & 1.000 & 0.952 & 1.000 & -0.074 & $-4.96^{* * *}$ & 0.000 & $-4.91^{* * *}$ \\
\hline Prior SOP Vote & 0.056 & 0.230 & 0.000 & 0.030 & 0.000 & 0.071 & 0.000 & -0.041 & $-3.13^{* * *}$ & 0.000 & $-3.12^{* * *}$ \\
\hline $\ln (M V$ Equity) & 7.835 & 1.448 & 7.673 & 7.620 & 7.429 & 7.958 & 7.799 & -0.339 & $-4.09^{* * *}$ & -0.370 & $-4.42^{* * *}$ \\
\hline Abnormal Returns & 0.041 & 0.344 & -0.012 & 0.060 & -0.001 & 0.031 & -0.017 & 0.029 & 1.45 & 0.016 & 1.25 \\
\hline Return on Assets & 0.056 & 0.081 & 0.048 & 0.067 & 0.055 & 0.050 & 0.043 & 0.018 & $3.89^{* * *}$ & 0.012 & $3.85^{\text {*** }}$ \\
\hline
\end{tabular}


Panel B: Compensation and governance variables

\section{Full Sample}

\section{Triennial Recom.}

Annual Recom.

Triennial vs. annual recom.

\begin{tabular}{|c|c|c|c|c|c|c|c|c|c|c|c|}
\hline \multirow[t]{2}{*}{ Variable } & \multirow[t]{2}{*}{ Mean } & \multirow[t]{2}{*}{ Std. Dev. } & \multirow[t]{2}{*}{ Median } & \multirow[t]{2}{*}{ Mean } & \multirow[t]{2}{*}{ Median } & \multirow[t]{2}{*}{ Mean } & \multirow[t]{2}{*}{ Median } & \multicolumn{2}{|c|}{ Mean (t-test) } & \multicolumn{2}{|c|}{ Median (Wilcoxon) } \\
\hline & & & & & & & & Difference & t-statistic & Difference & z-statistic \\
\hline CEO Pay Duration & 1.460 & 0.205 & 1.460 & 1.456 & 1.460 & 1.463 & 1.460 & -0.006 & -0.60 & 0.000 & -0.92 \\
\hline Book-to-Market Ratio & 0.681 & 0.240 & 0.703 & 0.656 & 0.675 & 0.696 & 0.712 & -0.040 & $-2.88^{* * *}$ & -0.038 & $-2.86^{* * *}$ \\
\hline$R \& D /$ Total Assets & 0.024 & 0.050 & 0.000 & 0.024 & 0.000 & 0.023 & 0.000 & 0.001 & 0.30 & 0.000 & -0.32 \\
\hline Volatility & 0.021 & 0.007 & 0.020 & 0.022 & 0.021 & 0.021 & 0.020 & 0.001 & 1.59 & 0.000 & $1.69^{*}$ \\
\hline CEO Equity Pay Ratio & 0.582 & 0.276 & 0.668 & 0.539 & 0.618 & 0.606 & 0.687 & -0.067 & $-4.26^{* * *}$ & -0.069 & $-4.27^{* * *}$ \\
\hline CEO Total Pay & 5.613 & 5.372 & 3.983 & 5.240 & 3.407 & 5.830 & 4.318 & -0.590 & $-1.89^{*}$ & -0.911 & $-3.90^{* * *}$ \\
\hline Classified Board & 0.499 & 0.500 & 0.000 & 0.554 & 1.000 & 0.466 & 0.000 & 0.088 & $2.85^{* * *}$ & 1.000 & $2.84^{* * *}$ \\
\hline CEO-Chairman Duality & 0.536 & 0.502 & 1.000 & 0.547 & 1.000 & 0.530 & 1.000 & 0.017 & 0.55 & 0.000 & 0.59 \\
\hline Majority Voting & 0.375 & 0.484 & 0.000 & 0.289 & 0.000 & 0.425 & 0.000 & -0.136 & $-4.60^{* * *}$ & 0.000 & $-4.56^{* * *}$ \\
\hline$\%$ Independent Directors & 0.792 & 0.107 & 0.818 & 0.774 & 0.800 & 0.830 & 0.801 & -0.056 & $-4.13^{* * *}$ & -0.001 & $-4.10^{* * *}$ \\
\hline
\end{tabular}

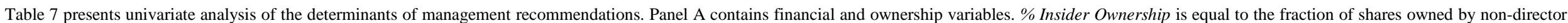

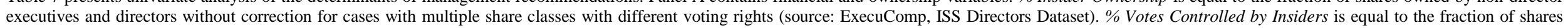

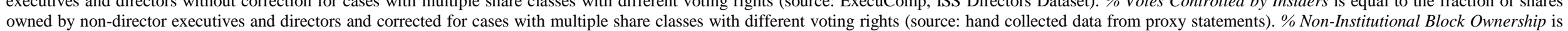

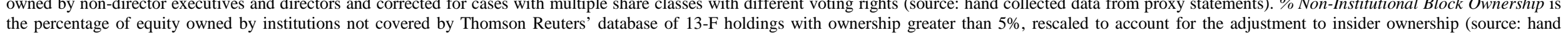

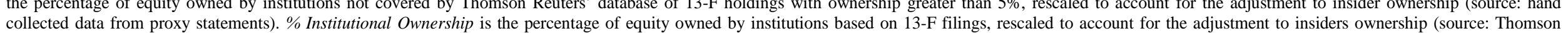

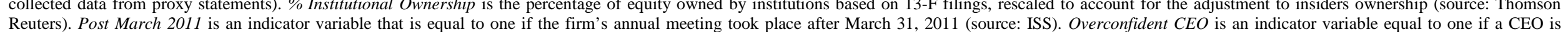

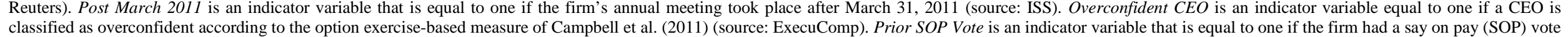

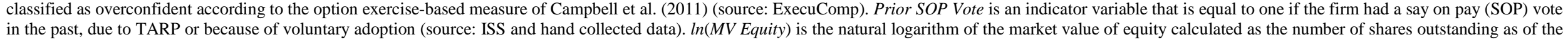
end of the most recent fiscal year ending before the annual meeting (Compustat data item $c$ sho) times price at fiscal year close (Compustat data item prcc_f) (source: Compustat). Abnormal Returns are size-adjusted returns

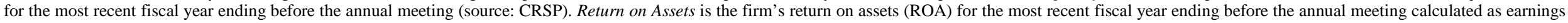
before extraordinary items (Compustat data item $i b$ ) scaled by average total assets (Compustat item $a t$ ) (source: Compustat). 
Panel B contains compensation and governance variables. CEO Pay Duration is the industry-level measure of CEO pay duration reported in Table 3 of Gopalan et al. (2012). Book-to-Market Ratio is the book value of equity (Compustat data item ceq) scaled by market value of equity (calculated as the number of shares outstanding as of the end of the most recent fiscal year ending before the annual meeting (Compustat data item $c s h o$ ) times price at fiscal year close (Compustat data item prcc_f)) (source: Compustat). $R \& D /$ Total Assets is computed as R\&D expenses (Compustat data item $x r d$ ) divided by total assets (Compustat data item $a t)$, with missing R\&D expenses set equal to 0 (source: Compustat). Volatility is the standard deviation of daily returns over the 12 month window prior to the annual meeting date (source: CRSP). CEO Equity Pay Ratio is equal to CEO Equity Pay divided by CEO Equity Pay plus CEO Cash Pay, where CEO Cash Pay is the sum of salary, bonus and other cash pay and CEO Equity Pay is the value of equity grants (restricted stock and stock options) (source: ExecuComp). CEO Total Pay is the total CEO compensation for the fiscal year prior to the annual meeting date and is comprised of salary, bonus, non-equity incentive plan compensation, grant-date fair value of option awards, grant-date fair value of stock awards, deferred compensation earnings reported as compensation and other compensation (source: ExecuComp). Classified Board is an indicator variable that is equal to one if the board of directors is classified (source: RiskMetrics). CEO-Chairman Duality is an indicator variable that is equal to one if the CEO of the company is also the chair of the board of directors and zero otherwise (source: ISS Directors Dataset). Majority Voting is an indicator variable that is equal to one if a company has adopted a majority voting election system (source: ISS). \% Independent Directors is the percentage of directors classified as independent by ISS (source: ISS Directors Dataset). ${ }^{* * *},{ }^{* *}$, and ${ }^{*}$ denote significance at the $0.01,0.05$, and 0.10 level, respectively, based on a two-tailed test. 
Table 8 Determinants of management recommendations on frequency of say on pay: Multivariate analysis

Panel A: The role of financial and ownership variables

\begin{tabular}{|c|c|c|}
\hline & $\begin{array}{c}\text { Model (1) } \\
\text { Coefficient } \\
\text { (z-statistic) }\end{array}$ & $\begin{array}{l}\text { Model (2) } \\
\text { Coefficient } \\
\text { (z-statistic) }\end{array}$ \\
\hline \multirow[t]{2}{*}{ Intercept } & $1.711^{* * *}$ & $1.609^{* * *}$ \\
\hline & $(2.972)$ & $(2.780)$ \\
\hline \multirow[t]{2}{*}{$\%$ Votes Controlled by Insiders } & $2.497^{* * *}$ & $2.542^{* * *}$ \\
\hline & $(4.584)$ & $(4.584)$ \\
\hline \multirow[t]{2}{*}{ \% Non-Institutional Block Ownership } & $1.930 *$ & $1.884^{*}$ \\
\hline & $(1.812)$ & $(1.761)$ \\
\hline \multirow[t]{2}{*}{$\%$ Institutional Ownership } & $-0.884^{* *}$ & \\
\hline & $(-2.166)$ & \\
\hline \multirow[t]{2}{*}{ \% Inst. Own. in Favor of Annual } & & $-2.051^{* *}$ \\
\hline & & $(-2.007)$ \\
\hline \multirow[t]{2}{*}{$\%$ Inst. Own. in Favor of Triennial } & & 1.821 \\
\hline & & $(0.819)$ \\
\hline \multirow[t]{2}{*}{$\%$ Inst. Own. With No Stated Preference } & & $-1.060^{* *}$ \\
\hline & & $(-2.416)$ \\
\hline \multirow[t]{2}{*}{ Post March 2011} & $-0.999^{* * * *}$ & $-0.992^{* * *}$ \\
\hline & $(-4.379)$ & $(-4.349)$ \\
\hline \multirow[t]{2}{*}{ Overconfident $C E O$} & $0.228^{*}$ & $0.220^{*}$ \\
\hline & $(1.802)$ & $(1.737)$ \\
\hline \multirow[t]{2}{*}{ Prior SOP Vote } & -0.515 & $-0.529^{*}$ \\
\hline & $(-1.601)$ & $(-1.652)$ \\
\hline \multirow[t]{2}{*}{$\ln (M V$ Equity $)$} & $-0.144^{* * *}$ & $-0.133^{* * *}$ \\
\hline & $(-3.081)$ & $(-2.812)$ \\
\hline \multirow[t]{2}{*}{ Abnormal Returns } & 0.152 & 0.183 \\
\hline & $(0.852)$ & $(1.015)$ \\
\hline \multirow[t]{2}{*}{ Return on Assets } & $2.811^{* * *}$ & $2.874^{* * *}$ \\
\hline & $(3.577)$ & $(3.604)$ \\
\hline $\mathrm{N}$ & 1,308 & 1,308 \\
\hline Pseudo R ${ }^{2}$ & 0.071 & 0.074 \\
\hline
\end{tabular}


Panel B: The role of compensation and governance characteristics

\begin{tabular}{|c|c|c|c|c|}
\hline & $\begin{array}{c}\text { Model (1) } \\
\text { Coefficient } \\
\text { (z-statistic) }\end{array}$ & $\begin{array}{l}\text { Model (2) } \\
\text { Coefficient } \\
\text { (z-statistic) }\end{array}$ & $\begin{array}{c}\text { Model (3) } \\
\text { Coefficient } \\
\text { (z-statistic) }\end{array}$ & $\begin{array}{c}\text { Model (4) } \\
\text { Coefficient } \\
\text { (z-statistic) }\end{array}$ \\
\hline CEO Pay Duration & $\begin{array}{r}-0.084 \\
(-0.266)\end{array}$ & $\begin{array}{r}-0.071 \\
(-0.226)\end{array}$ & $\begin{array}{r}-0.094 \\
(-0.296)\end{array}$ & $\begin{array}{r}-0.111 \\
(-0.318)\end{array}$ \\
\hline Book-to-Market Ratio & $\begin{array}{r}-0.145 \\
(-0.408)\end{array}$ & $\begin{array}{r}-0.228 \\
(-0.637)\end{array}$ & $\begin{array}{r}-0.255 \\
(-0.704)\end{array}$ & $\begin{array}{r}-0.318 \\
(-0.762)\end{array}$ \\
\hline$R \& D /$ Total Assets & $\begin{array}{r}-0.418 \\
(-0.308)\end{array}$ & $\begin{array}{r}-0.348 \\
(-0.258)\end{array}$ & $\begin{array}{r}-0.416 \\
(-0.308)\end{array}$ & $\begin{array}{r}0.287 \\
(0.189)\end{array}$ \\
\hline Volatility & $\begin{array}{r}-6.952 \\
(-0.671)\end{array}$ & $\begin{array}{r}-8.715 \\
(-0.835)\end{array}$ & $\begin{array}{r}-6.140 \\
(-0.566)\end{array}$ & $\begin{array}{r}-1.261 \\
(-0.101)\end{array}$ \\
\hline CEO Equity Pay Ratio & $\begin{array}{r}-0.402 \\
(-1.643)\end{array}$ & $\begin{array}{l}-0.556^{* *} \\
(-2.130)\end{array}$ & $\begin{array}{l}-0.551^{* *} \\
(-2.090)\end{array}$ & $\begin{array}{l}-0.743^{\text {** }} \\
(-2.538)\end{array}$ \\
\hline CEO Total Pay & & $\begin{array}{c}0.026^{*} \\
(1.700)\end{array}$ & & \\
\hline CEO Residual Pay & & & $\begin{array}{l}0.034^{* *} \\
(1.970)\end{array}$ & $\begin{array}{c}0.031 \\
(1.776)\end{array}$ \\
\hline CEO Expected Pay & & & $\begin{array}{r}-0.011 \\
(-0.310)\end{array}$ & $\begin{array}{r}-0.003 \\
(-0.072)\end{array}$ \\
\hline Classified Board & & & & $\begin{array}{r}0.244^{*} \\
(1.820)\end{array}$ \\
\hline CEO-Chairman Duality & & & & $\begin{array}{r}0.143 \\
(1.057)\end{array}$ \\
\hline Majority Voting & & & & $\begin{array}{r}-0.279^{*} \\
(-1.795)\end{array}$ \\
\hline$\%$ Independent Directors & & & & $\begin{array}{r}-0.352 \\
(-0.528)\end{array}$ \\
\hline Controls & Included & Included & Included & Included \\
\hline $\mathrm{N}$ & 1,288 & 1,288 & 1,277 & 1,128 \\
\hline Pseudo $\mathrm{R}^{2}$ & 0.076 & 0.078 & 0.078 & 0.077 \\
\hline
\end{tabular}

Table 8 presents the results for the determinants of a management recommendation to hold triennial SOP votes. The dependent variable is an indicator variable that is equal to one if management recommends holding triennial SOP votes and zero if management recommends annual SOP votes. Panel A reports the results for a benchmark model and additional institutional ownership structure variables.

$\%$ Votes Controlled by Insiders is equal to the fraction of shares owned by non-director executives and directors and corrected for cases with multiple share classes with different voting rights (source: ExecuComp, ISS Directors Dataset and hand collected data). $\%$ Non-Institutional Block Ownership is the percentage of equity owned by institutions not covered by Thomson Reuters' database of 13-F holdings with ownership greater than 5\% (source: hand collected data). \% Institutional Ownership is the percentage of equity owned by institutions based on 13-F filings (source: Thomson Reuters). \% Institutional Ownership in Favor of Annual (Triennial) is the percentage of equity owned by $13-\mathrm{F}$ institutions that have expressed a preference for annual (triennial) SOP votes (source: Hauder 2011, Thomson Reuters and hand collected data). \% Institutional Ownership With No Stated Preference is the percentage of equity owned by 13-F institutions that have expressed no preference for annual or triennial SOP votes (source: Hauder 2011, Thomson Reuters and hand collected data). Post March 2011 is an indicator variable that is equal to one if the firm's annual meeting took place after March 31, 2011 (source: ISS). Overconfident CEO is an indicator variable equal to one if a CEO is classified as overconfident according to the option exercise-based measure of Campbell et al. (2011) (source: ExecuComp). Prior SOP Vote is an indicator variable that is equal to one if the firm had a SOP vote in the past year, due to TARP or because of voluntary adoption (source: ISS and hand collected data). $\ln (M V$ Equity) is the natural logarithm of the market value of equity calculated as the number of shares outstanding as of the end of the most recent fiscal year ending before the annual meeting (Compustat data item $c s h o$ ) times price at fiscal year close (Compustat data item prcc_f) (source: Compustat). Abnormal Returns 
are size-adjusted returns for the most recent fiscal year ending before the annual meeting (source: CRSP). Return on Assets is the firm's return on assets (ROA) for the most recent fiscal year ending before the annual meeting calculated as earnings before extraordinary items (Compustat data item $i b$ ) scaled by average total assets (Compustat item at) (source: Compustat).

Panel B reports the results for compensation and governance variables. All the control variables from Panel A Model 1 are included but suppressed for ease of exposition. Additional variables include: CEO Pay Duration is the measure of CEO pay duration reported in Table 3 of Gopalan et al. (2012). Book-to-Market Ratio is the book value of equity (Compustat data item ceq) scaled by market value of equity (calculated as the number of shares outstanding as of the end of the most recent fiscal year ending before the annual meeting (Compustat data item $c s h o$ ) times price at fiscal year close (Compustat data item prcc_f)) (source: Compustat). $R \& D$ / Total Assets is $\mathrm{R} \& \mathrm{D}$ expenses (Compustat data item $x r d$ ) divided by total assets (Compustat data item at), with missing $\mathrm{R} \& \mathrm{D}$ expenses set equal to 0 (source: Compustat). Volatility is the standard deviation of daily returns over the 12 month window prior to the annual meeting date (source: CRSP). CEO Equity Pay Ratio is equal to CEO Equity Pay divided by CEO Equity Pay plus CEO Cash Pay, where CEO Cash Pay is the sum of salary, bonus and other cash pay and CEO Equity Pay is the value of equity grants (restricted stock and stock options) (source: ExecuComp). CEO Total Pay is the total CEO compensation for the fiscal year prior to the annual meeting date and is comprised of salary, bonus, non-equity incentive plan compensation, grant-date fair value of option awards, grant-date fair value of stock awards, deferred compensation earnings reported as compensation and other compensation (source: ExecuComp). CEO Expected Pay is the exponent of the predicted value from a regression of the natural logarithm of total CEO compensation on proxies for economic determinants of CEO compensation (see Section 5.2) (source: ExecuComp). CEO Residual Pay is CEO Total Pay less CEO Predicted Total Pay. Classified Board is an indicator variable that is equal to one if the board of directors is classified (source: RiskMetrics). CEO-Chairman Duality is an indicator variable that is equal to one if the CEO of the company is also the chair of the board of directors and zero otherwise (source: ISS Directors Dataset). Majority Voting is an indicator variable that is equal to one if a company has adopted a majority voting election system (source: ISS). \% Independent Directors is the percentage of directors classified as independent by ISS (source: ISS Directors Dataset).

${ }^{* * *},{ }^{* *}$, and ${ }^{*}$ denote significance at the $0.01,0.05$, and 0.10 level, respectively, based on a two-tailed test. Reported $z$-statistics are based on robust standard errors. 